\title{
ERGONOMIK PERSONEL ÇİZELGELEME VE PERAKENDE SEKTÖRÜNDE BİR UYGULAMA
}

\author{
Neşet BEDIR'1, Tamer EREN¹, Ercüment Neşet DiZZDAR²
}

${ }^{1}$ Kırıkkale Üniversitesi, Mühendislik Fakültesi, Endüstri Mühendisliği Bölümü, Kırıkkale, Türkiye ${ }^{2}$ Çankırı Karatekin Üniversitesi, Yapraklı Meslek Yüksek Okulu, Mülkiyet Koruma ve Güvenlik Bölümü, Çankırı, Türkiye

\begin{tabular}{ll}
\hline Anahtar Kelimeler & Özet \\
\hline $\begin{array}{l}\text { Ergonomik riskfaktörü, } \\
\text { vardiya çizelgeleme, }\end{array}$ & Firmaların verimliliğini etkileyen önemli sebeplerden biri de personel \\
Hedef programlama, & memnuniyetidir. Personel memnuniyetinde çalışma koşullarının dengeli bir şekilde \\
AHP. & dağıtılması ve çalışma ortamındaki fiziksel faaliyetleri dikkate alınarak çalışma \\
& saatlerinin düzenlenmesi önemli rol oynamaktadır. Literatürde yapılan çalışmalar \\
& incelendiğinde ergonomik faaliyetleri de dikkate alan vardiya çizelgeleme \\
& çalışmaları oldukça kısıtlı sayıdadır. \\
& Bu çalışmada da ergonomik koşullar dikkate alan vardiya çizelgeleme problemi ele \\
& alınmıştır. Uygulama yeri olarak Uluslararası piyasada 500'den fazla mağazası \\
& bulunan bir hazır giyim firmasının Kırıkkale'deki bir mağazası seçilmiştir. \\
& Problemde ergonomik risk faktörleri ve çalışma saatlerinin dengelenmesi \\
hedeflenmiştir. Problemin çözümünde analitik hiyerarşi süreci ve hedef \\
programlama yöntemleri kullanılmıştır. Çalışma 5 görev biriminde 39 personel için \\
aylık olarak yapılmıştır.
\end{tabular}

\section{ERGONOMIC STAFF SCHEDULING AND AN APPLICATION IN THE RETAIL SECTOR}

Keywords
Ergonomic risk factor,
Shift scheduling,
Goal programming,
AHP.

Alıntı / Cite

Bedir, N., Eren T., Dizdar E. N., (2017). Ergonomik Personel Çizelgeleme ve Perakende Sektöründe Bir Uygulama, Journal of Engineering Sciences and Design, 5(3), 657 - 674.

\section{Yazar Kimliği / Author ID (ORCID Number)}

N. Bedir, 0000-0002-8906-9194

T. Eren, 0000-0001-5282-3138

E. N. Dizdar, 0000-0002-4607-9039

\begin{tabular}{ll}
\hline Başvuru Tarihi /Submission Date & 27.07 .2017 \\
Kabul Tarihi / Accepted Date & 01.12 .2017 \\
Yayım Tarihi / Published Date & 25.12 .2017 \\
\hline
\end{tabular}

* İletişim yazarı / Corresponding author: teren@kku.edu.tr , 0 (318) 3574242-1050 


\section{Giriş}

Personel planlaması, genellikle yoğun bir zaman alan ve maliyet açısından önemli bir görevdir. Bu nedenle, üretim ya da hizmet sektörlerinden herhangi bir kuruluş için ana yönetim endişelerinden birini temsil eder (Rocha vd., 2012). Doğru çizelgenin oluşturulmaması işçiler arasında iş yükü dengesini bozarak işçinin memnuniyetsizliğine neden olabilir.

Vardiya çizelgeleme probleminin, gün içinde veya belirli periyotlarda değișen müșteri istekleri ile karşı karşıya kalan organizasyonlar için çok kritik bir rolü vardır. Vardiya personellerinin planlanması bir hizmet sisteminin en zorlu görevi olmakla birlikte, doğru yapıldığı taktirde işletmelere büyük getiriler sağlayabilmektedir (Topaloglu ve Özkarahan, 2003).

Bu çalışma iç ve dış pazarda etkin rol oynayan bir hazır giyim firmasının Kırıkkale'deki bir mağazada vardiya çizelgeleme problemi ele alınmıştır. Problemin çözümünde ergonomik risk faktörleri ve çalışma saatlerinin dengelenmesi için Hedef programlama yöntemi kullanılmıştır. Mağazada bulunan Reyon, Depo, yönetim, kasa ve temizlik bölümlerinde görev yapmakta olan 39 personel için bir aylık çizelge hazırlanmıştır.

Çalışmanın planı şu şekildedir. İkinci bölümde ergonomik personel çizelgeleme problemi anlatılmıştır. Üçüncü bölümde AHP yöntemi anlatılmıștır. Dördüncü bölümde literatürde ergonomik faktörleri dikkate alarak yapılan çizelgeleme çalışmalarına yer verilmiştir. Beşinci bölümde yapılan uygulamaya yer verilmiştir. Altıncı bölüm olan son bölümde yazının sonuç ve çıkarımlarına yer verilerek gelecekte yapılabilecek çalışmalara öneriler getirilmiştir.

\section{Ergonomik Personel Çizelgeleme}

İş gücünün etkin çizelgelenmesi hizmet sistemlerinin önemli problemlerinden birisidir. İşgücünün doğru planlanmaması durumunda, personel eksikliği hizmet kalitesinin zayıf kalmasına neden olmakta, fazlalığı ise gereksiz kaynak kullanımına neden olmaktadır (Seçkiner ve Kurt, 2005). İş rotasyonu, üretim sistemlerinde gittikçe artan bir şekilde kullanılan bir organizasyon stratejisidir; çünkü bir kuruluştaki hem işçilere hem de yönetimlere fayda sağlar. İş rotasyonu, kas-iskelet bozukluklarını önler, sıkıntıyı ortadan kaldırır ve iş tatmini ve moralini artırır. Sonuç olarak, şirket üretkenlik, çalışan bağlılığı ve çalışanların cirosundaki azalmalara yol açan nitelikli ve motivasyonlu bir işgücü kazanır. Yorulma birikiminin neden olduğu kas-iskelet bozukluklarını önlemek için en uygun personel görevini göz önüne alarak, iş rotasyon çizelgelerini oluşturmak için çok kriterli bir genetik algoritma kullanılır. Algoritma, işçiler arasında mevcut en iyi yeterliliği ve görevleri yerine getirmek için gereken yeterlilikleri sağlar. Rotasyon programlarının tasarımı sadece ergonomik kriterlere değil, aynı zamanda ürün kalitesine ve çalışanların memnuniyetine ilişkin konulara da dayanmaktadır. Model, çözümlerin iyiliği için bir ölçüt olarak işçilerin yetkinliklerini içerir (Asensio-Cuesta vd., 2012).

\section{Materyal ve Yöntem}

\subsection{Hedef Programlama Yöntemi}

Hedef programlama Charnes ve Cooper (1961) tarafından ortaya atılmıştır. 1970’li yıllarda Lee (1972)'nin çalışmalarıyla geliştirilmiş olan model doğrusal programlamada olduğu gibi amaç kriterinin doğrudan maksimize veya minimize yapılmasının yerine, hedefler arasındaki sapmalar minimize eder. Doğrusal programlamanın simplex algoritmasında yer alan bu gibi sapmalar aylak değișkenler olarak isimlendirilirken, bu sapan değişkenler hedef programlamada yeni bir anlam kazanırlar. Sapma değişken olarak adrandırılan bu karar değișkenleri her bir hedeften hem pozitif yönde hem de negatif yönde sapmalar şeklinde iki boyutta gösterilir (Körpeli vd., 2011).

$\mathrm{x}_{\mathrm{j}}$ : j. karar değişkeni

$\mathrm{a}_{\mathrm{ij}}$ : i. hedefin j. karar değişkeni katsayıları

$b_{\mathrm{i}}:$ i. hedef için hedeflenen değer

$d_{i}^{+}:$i. hedefin pozitif sapma değeri

$\mathrm{d}_{\mathrm{i}}^{-}$: i. hedefin negatif sapma değeri

$\operatorname{Min} \mathrm{Z}=\sum_{i=1}^{m}\left(d_{i}^{+}+d_{i}^{-}\right)$

Hedef programlamada i bir hedef için genel gösterim şu şekildedir;

$$
\begin{aligned}
& \sum_{j=1}^{n} a_{i j} * x_{i j}-d_{i}^{+}+d_{i}^{-}=b_{i} \quad i=1, . ., m \\
& d_{i}^{+}, d_{i}^{-}, x_{j} \geq 0 \quad i=1, . ., m \quad j=1, . ., n
\end{aligned}
$$

\subsection{AHP Yöntemi}

AHP yöntemi 1977 yılında Saaty tarafından geliştirilen bir çok kriterli karar verme (ÇKKV) yöntemidir (Wind ve Saaty,1980). Analitik Hiyerarşi Prosesi şirketlerin karmaşık ve çok kriterli problemlerinin alt ve üst yönetime anlatımı ve bilgi paylaşımında hiyerarşik gösterimi sayesinde kolaylık sağlamaktadır.

Birçok uygulamaya esas oluşturan Analitik Hiyerarşi Sürecinin adımları aşağıda verilmiştir (Millet ve Saaty, 2000): 
Adım 1: Hiyerarşik Yapının Oluşturulması

Adım 2: Önceliklerin Belirlenmesi

Adım 3: İkili Karşılaştırma Matrisi ve Çözümü

Adım 4: Normalleştirme ve Göreli Önem Ağırlıkları

Adım 5: Tutarlılık Oranının Hesaplanması

Adım 6: Nihai Sıranın Belirlenmesi

\section{Literatürde Yer Alan Çalışmalar}

Bu bölümde literatürde ergonomik iş gücü çizelgeleme ile ilgili yapılan bazı çalışmalara yer verilmiştir.

Beaumont (1997) çalışmasında iş gücü planlama problemi için karışık tamsayılı programlama modeli önermiştir. Günün belirli saatlerinde ve hafta içi değişen talebi karşılayacak bir işgücünün planlanması sorununa çözüm önerilmektedir. Çalışma sonucunda kaç personel istihdam edileceğini ve hangi saatlerde vardiyalı çalıştırılacağını belirlemişlerdir. Azmat vd. (2004) çalışmalarında, tek bir vardiya için işgücü planlama problemini çözmek için dört karma tamsayı programlama modeli geliştirilmişlerdir. Yıllıklandırılmış saat senaryosu ile minimum gerekli iş gücünü elde etmişlerdir. Abbink vd. (2005) çalışmalarında demiryolu operatörlerini çizelgelemişlerdir. Çalışma sonucunda verimlilikte çok ciddi iyileştirmeler elde etmişlerdir. Bard ve Wan (2006) çalışmalarında homojen işgücü dağılımını sağlamak amacıyla, bir başka deyişle iş istasyonu grupları arasındaki geçişlerin ağırlıklı toplamını en aza indirmek için bir çizelge oluşturmuşlardır. Aickelin vd. (2006) çalışmalarında farklı yönlerden bir vardiyanın yapısını değerlendirmek için beş kriter belirleyerek her kriteri belli belirsizlik derecesine sahip olduğundan bulanık değerlendirme yöntemi ile bu üyelik işlevlerini bir araya getirmişlerdir. Daha sonra metasezgisel algoritma uygulanarak her iterasyon sırasında kırık çizelgeler yapısal sezgisel yöntemle onarmışlardır. Alfares (2007) çalışmasında günlük emek talepleri rastgele değişkenler olduğu bir tesiste çalışanlar için bir simülasyon yaklaşımı sunulmaktadır. Model, sınırlı çalışanların mevcudiyeti, stokastik iş yükü değişkenliği ve çalışanların çalışma programlarının seçimine ilişkin politika kısıtlamalarını tanır. Model, bir petrol ve gaz boru hattı bölümünün çok merkezli bir bakım işçisinin günler arası kapanış planlamasında başarıyla uygulanmıştır. Narlı (2007) çalışmasında bir üniversite hastanesinin yoğun bakım ünitesinde görev yapan hemşirelerin çizelgelemelerini yapmıştır. AlYakoob ve Sherali (2008) çalışmalarında çalışanları belirli vardiyalar, kapalı yerler ve çalışma merkezleri için ifade ettikleri tercihleri göz önüne alarak bir dizi çalışma merkezine atama sorunu ile ilgilenmişlerdir. Çalışmada Kuveyt Ulusal Petrol Şirketinde bulunan 86 istasyonda çalışanların işlere atanmasını amaçlamışlardır. Problemi karışık tamsayılı programlama modelindeki ile modellemişlerdir. Carnahan vd. (2000) çalışmalarında yaralanma potansiyelini düşüren iş rotasyon çizelgelerini üretmek için emniyet kriterlerini çizelgeleme algoritmalarına dahil etme yöntemleri geliştirmişlerdir. İş rotasyon çizelgelerini oluşturmak için tamsayı programlama ve bir genetik algoritma kullanılmıştır. Çizelgeler, yaralanma potansiyeli İş Önem Derecesi Endeksi (Job Severity Index) ile değerlendirerek bir çalışma ortamında belirli güvenlik kriterlerine uyan dört iş rotasyon programını tasarlamak için kullanılmışlardır. Rocha vd. (2012) çalışmalarında bir cam fabrikası ve bir sürekli bakım ünitesinin çizelgeleme problemi için karma tamsayılı programlama ile bir model önermişlerdir. Wongwien ve Nanthavanij (2012a) çalışmalarında ergonomik işgücü planlaması problemini ele almışlardır. Çalışmada yapılacak işlerin personel gereksinimleri, işlere heterojen şekilde işçi atanabilecek şekilde ergonomik risk faktörlerinde izin verilen sınırın aşılmaması amaçlanmıştır. Wongwien ve Nanthavanij (2012b) çalışmalarında işçilerin günlük gürültü riskini izin verilen bir sınırda tutacak şekilde iş istasyonları arasında atama yapmışlardır. İzim verilen gürültü sınırını aşmayacak şekilde çalışması gereken en az işçi sayısını bulmayı amaçlamışlardır. Otto ve Scholl (2013) çalışmalarında işçiler arasında ergonomik riskleri dengeleyen etkin iş rotasyon programlarının oluşturmuşlardır. Otomobil endüstrisindeki örnekler üzerinde kapsamlı bir şekilde tartışmışlardır. Bektur ve Hasgül (2013) çalışmalarında bir restoranın çalışanlarının kıdem seviyeleri, becerileri, kişisel tercihleri ve işletme taleplerini dikkate alınarak çizelgelesini oluşturmuşlardır. Dewi ve Septiana (2015) bir lojistik şirketinin işçi atama problemini ele almışlardır. İşin gerekliliklerine uygun işçiyi doğru yerde tahsis etmek için işgücü planlaması yapmışlardır. Uygun olmayan iş gücü planlaması, Çalışmada önce fiziksel ve zihinsel iş yükü olmak üzere iş yükünü ölçmüşlerdir. Zihinsel ölçümleri NASA-TLX, fiziksel iş yükü ölçümü için kullanılan yöntem ise Endonezya Ulusal Standardı'na (SNI) dayalı kalori sarfiyatlarına dayandırmışlardır. Bu faktörler göz önüne alınarak iş yükünü dengelemek için bir işgücü planlama modeli tasarlamışlardır. Varlı (2017) 
çalışmasında formenlerin vardiyalarını çizelgelemelerini AHP ve hedef programlama ile gerçekleştirmiştir. Kurduğu modelde firma için farklı senaryolar önermiștir. Eren ve Varlı (2017) çalışmalarında 3 vardiya üretim yapan bir fabrikada çalışan şeflerin izin günlerini düzenlemek, işgücünü dengeli ve adaletli dağıtmak ve kıdem seviyelerini kullanarak șefleri vardiyalara atamak için bir model önermişlerdir. Varlı vd. (2016) metroda vatmanların Varlı vd. (2017) sınav görevlilerinin, Özder vd. (2017) temizlik personelinin, Özcan vd. (2017) hidroelektrik santrallerde çalışanların, Ciritcioğlu vd. (2017) güvenlik görevlilerinin vardiya atama problemlerini hedef programlama yöntemi ile çözmüşlerdir.

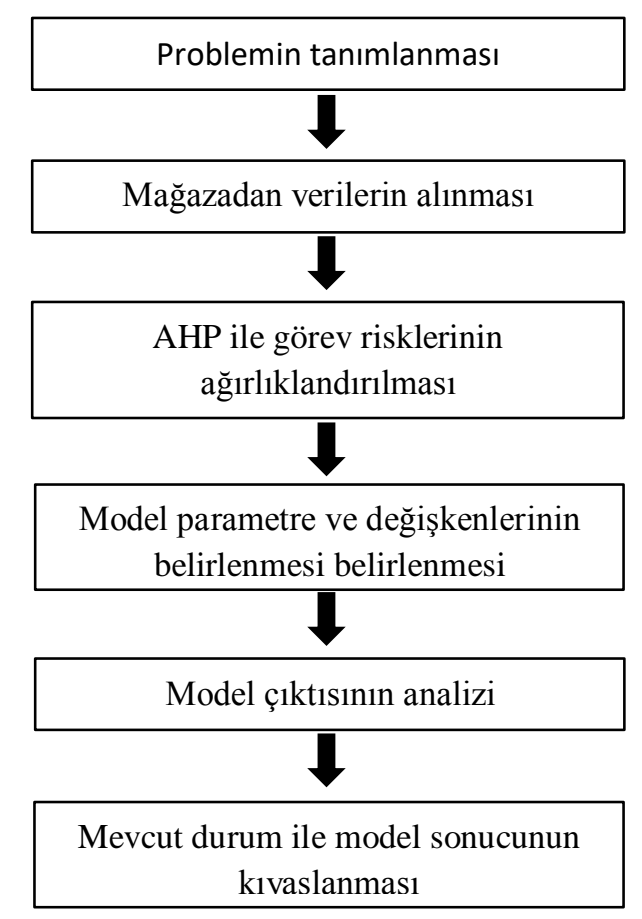

Şekil 1.Uygulama akış şeması

\section{Uygulama}

Çalışmanın akış planı Şekil 1'de gösterildiği gibidir.

Tablo 1. Görevler hakkında genel bilgiler

\begin{tabular}{|c|c|c|c|c|c|c|c|c|c|c|c|c|c|}
\hline \multirow{2}{*}{$\begin{array}{l}\text { Görev } \\
\text { Birimi }\end{array}$} & \multirow{2}{*}{$\begin{array}{c}\text { Görev } \\
\text { No }\end{array}$} & \multirow{2}{*}{ Görev } & \multicolumn{7}{|c|}{ Gerekli personel sayısı } & \multicolumn{4}{|c|}{ Görev periyodu } \\
\hline & & & $\mathrm{Pa}$ & Sa & Ça & $\mathrm{Pe}$ & $\mathrm{Cu}$ & $\mathrm{Ct}$ & $\mathrm{Pz}$ & 1 & 2 & 3 & 4 \\
\hline Kasa & 1 & İșlem alma & 3 & 3 & 3 & 3 & 4 & 6 & 6 & G & $\mathrm{G}$ & G & $\mathrm{G}$ \\
\hline Kasa & 2 & Kasa düzen & 1 & 1 & 1 & 1 & 1 & 1 & 1 & G & & & $G$ \\
\hline Reyon & 3 & Kabin & 3 & 3 & 3 & 3 & 3 & 3 & 3 & G & G & G & $\mathrm{G}$ \\
\hline Reyon & 4 & Reyon düzen & 2 & 2 & 2 & 2 & 2 & 2 & 2 & $\mathrm{G}$ & $\mathrm{G}$ & $\mathrm{G}$ & $\mathrm{G}$ \\
\hline Reyon & 5 & Stș. Danș. & 3 & 3 & 3 & 3 & 4 & 8 & 8 & G & $\mathrm{G}$ & G & $G$ \\
\hline Reyon & 6 & Transfer & - & - & 3 & - & - & - & - & $\mathrm{G}$ & $\mathrm{G}$ & $\mathrm{G}$ & \\
\hline Reyon & 7 & Koli açma & 1 & 1 & 1 & 1 & 1 & 2 & 2 & G & $\mathrm{G}$ & G & $\mathrm{G}$ \\
\hline Depo & 8 & Sevkiyat kabul & 1 & - & - & - & - & - & - & G & $\mathrm{G}$ & & \\
\hline Depo & 9 & Alarm & 1 & 2 & 1 & 1 & 1 & - & - & G & $\mathrm{G}$ & G & $\mathrm{G}$ \\
\hline Depo & 10 & Ürün giriș & 1 & 1 & 1 & 1 & 1 & 1 & 1 & G & G & G & G \\
\hline Temizlik & 11 & Genel temizlik & 1 & - & 1 & 1 & 1 & 1 & 1 & $\mathrm{G}$ & & & $\mathrm{G}$ \\
\hline Temizlik & 12 & Mob atmak & 1 & 1 & 2 & 2 & 2 & 3 & 3 & & G & G & $\mathrm{G}$ \\
\hline İDARE & 13 & Yönetim & 1 & 2 & 1 & 2 & 2 & 2 & 2 & G & G & G & $\mathrm{G}$ \\
\hline
\end{tabular}


Tablo 2. Personellerin görev yetkinliği

\begin{tabular}{|c|c|c|c|c|c|c|c|c|c|c|c|c|c|c|}
\hline \multirow{2}{*}{ No } & \multirow{2}{*}{ Personel } & \multicolumn{13}{|c|}{ Görev yetkinliği } \\
\hline & & 1 & 2 & 3 & 4 & 5 & 6 & 7 & 8 & 9 & 10 & 11 & 12 & 13 \\
\hline 1 & Müdür & & 1 & & & & & & 1 & & & & & 1 \\
\hline 2 & Müdür yrd. & & 1 & & 1 & & & & 1 & & & & & 1 \\
\hline 3 & Reyon y. & 1 & 1 & & 1 & & 1 & & & & & & & 1 \\
\hline 4 & Reyon y. & 1 & 1 & & 1 & & 1 & & & & & & & 1 \\
\hline 5 & Reyon y. & 1 & 1 & & 1 & & 1 & & & & & & & \\
\hline 6 & Depo y. & & & & & & & & 1 & 1 & 1 & & & \\
\hline 7 & Kasa y. & 1 & 1 & & & & & & & & & & & \\
\hline 8 & Tam zamanlı & 1 & & 1 & & 1 & 1 & 1 & & 1 & 1 & & 1 & \\
\hline 9 & Tam zamanlı & 1 & & 1 & & 1 & 1 & 1 & & 1 & 1 & & 1 & \\
\hline 10 & Tam zamanlı & 1 & & 1 & & 1 & 1 & 1 & & 1 & 1 & & 1 & \\
\hline 11 & Tam zamanlı & 1 & & 1 & & 1 & 1 & 1 & & 1 & 1 & & 1 & \\
\hline 12 & Tam zamanlı & 1 & & 1 & & 1 & 1 & 1 & & 1 & 1 & & 1 & \\
\hline 13 & Tam zamanlı & 1 & & 1 & & 1 & 1 & 1 & & 1 & 1 & & 1 & \\
\hline 14 & Tam zamanlı & 1 & & 1 & & 1 & 1 & 1 & & 1 & 1 & & 1 & \\
\hline 15 & Tam zamanlı & 1 & & 1 & & 1 & 1 & 1 & & 1 & 1 & & 1 & \\
\hline 16 & Tam zamanlı & 1 & & 1 & & 1 & 1 & 1 & & 1 & 1 & & 1 & \\
\hline 17 & Tam zamanlı & 1 & & 1 & & 1 & 1 & 1 & & 1 & 1 & & 1 & \\
\hline 18 & Tam zamanlı & 1 & & 1 & & 1 & 1 & 1 & & 1 & 1 & & 1 & \\
\hline 19 & Tam zamanlı & 1 & & 1 & & 1 & 1 & 1 & & 1 & 1 & & 1 & \\
\hline 20 & Tam zamanlı & & & & & & & & & & & 1 & 1 & \\
\hline 21 & Yarı zamanlı & 1 & & 1 & & 1 & & 1 & & 1 & & & 1 & \\
\hline 22 & Yarı zamanlı & 1 & & 1 & & 1 & & 1 & & 1 & & & 1 & \\
\hline 23 & Yarı zamanlı & 1 & & 1 & & 1 & & 1 & & 1 & & & 1 & \\
\hline 24 & Yarı zamanlı & 1 & & 1 & & 1 & & 1 & & 1 & & & 1 & \\
\hline 25 & Yarı zamanlı & 1 & & 1 & & 1 & & 1 & & 1 & & & 1 & \\
\hline 26 & Yarı zamanlı & 1 & & 1 & & 1 & & 1 & & 1 & & & 1 & \\
\hline 27 & Yarı zamanlı & 1 & & 1 & & 1 & & 1 & & 1 & & & 1 & \\
\hline 28 & Yarı zamanlı & 1 & & 1 & & 1 & & 1 & & 1 & & & 1 & \\
\hline 29 & Yarı zamanlı & & & & & & & & & & & 1 & 1 & \\
\hline 30 & Kısmi zamanlı & & & 1 & & 1 & & & & 1 & & & 1 & \\
\hline 31 & Kısmi zamanlı & & & 1 & & 1 & & & & 1 & & & 1 & \\
\hline 32 & Kısmi zamanlı & & & 1 & & 1 & & & & 1 & & & 1 & \\
\hline 33 & Kısmi zamanlı & & & 1 & & 1 & & & & 1 & & & 1 & \\
\hline 34 & Kısmi zamanlı & & & 1 & & 1 & & & & 1 & & & 1 & \\
\hline 35 & Kısmi zamanlı & & & 1 & & 1 & & & & 1 & & & 1 & \\
\hline 36 & Kısmi zamanlı & & & 1 & & 1 & & & & 1 & & & 1 & \\
\hline 37 & Kısmi zamanlı & & & 1 & & 1 & & & & 1 & & & 1 & \\
\hline 38 & Kısmi zamanlı & & & 1 & & 1 & & & & 1 & & & 1 & \\
\hline 39 & Kısmi zamanlı & & & 1 & & 1 & & & & 1 & & & 1 & \\
\hline
\end{tabular}

\subsection{Problem Tanımı}

Kırıkkale Podium AVM 'de faaliyet gösteren bir giyim mağazasının bir aylık vardiya çizelgelemesi yapılacaktır. Mağazada gerçekleştirilecek 13 görev bulunmaktadır. Bir iş günü 4 eşit çalışma süresine bölünür. Her görev konumunda, çalışma süresi başına ergonomik risk miktarları bilinir. Mağaza sabah 10.00 'da açlıp akşam 10.00 'da kapatılmaktadır. Amaç personellerin dengeli iş gücü planı oluşturmaktır. Tablo 1'de her bir görevin hafta bazında ihtiyaç duyulan personel sayıları ve gün içinde işin yapılıp 
yapılmama durumunu gösteren görev periyodu gösterilmiştir.

Personellerin kıdemlerine ve eğitimlerine göre görev yetkinlikleri Tablo 2'de gösterilmektedir.

\section{2. İşlerin Ergonomik Risklerinin AHP yöntemi ile ağırlıklandırılması}

Yapılan uygulama ortamının koşullarına göre belirlenen ergonomik kriterler; oturarak çalışma (OÇ), ayakta çalışma (AÇ), yük ile çalışma (YÇ), merdiven çlkma (MÇ), Eğilme (E) olarak belirlenmiştir. Belirlenen bu kriterlerin ağırlıkları AHP yöntemi ile hesaplanmıștır. Ergonomik kriterlerin karar matrisi Saaty 1-9 ölçeği kullanılarak Tablo 3'te gösterildiği gibi hesaplanmıştır.

Tablo 3. AHP yöntemi karar matrisi

\begin{tabular}{|c|c|c|c|c|c|}
\hline Kriterler & OÇ & AC & YÇ & MÇ & E \\
\hline OÇ & 1 & 0,14 & 0,11 & 0,2 & 0,33 \\
\hline $\mathrm{AC}$ & 7 & 1 & 0,2 & 0,5 & 1 \\
\hline $\mathrm{YCC}$ & 9 & 5 & 1 & 5 & 7 \\
\hline $\mathrm{MC}$ & 5 & 2 & 0,2 & 1 & 3 \\
\hline $\mathrm{E}$ & 3 & 1 & 0,14 & 0,33 & 1 \\
\hline
\end{tabular}

Oluşturulan matrisi normalize hali Tablo 4'te gösterilmektedir.

Tablo 4. Normalize edilmiş matris

\begin{tabular}{|c|c|c|c|c|c|}
\hline Kriterler & OÇ & AC & YÇ & MÇ & E \\
\hline OÇ & 0,04 & 0,02 & 0,07 & 0,03 & 0,03 \\
\hline AC & 0,28 & 0,11 & 0,12 & 0,07 & 0,08 \\
\hline YÇ & 0,36 & 0,55 & 0,60 & 0,71 & 0,57 \\
\hline MÇ & 0,2 & 0,22 & 0,12 & 0,14 & 0,24 \\
\hline E & 0,12 & 0,11 & 0,09 & 0,05 & 0,08 \\
\hline
\end{tabular}

Normalize matris elde edildikten sonra kriter ağırlıkları Tablo 5 'teki gibi hesaplanmıştır.

Her bir görevin ağırlığı bulunduktan sonra görevlerin ergonomik riskleri belirlenmiştir. Her bir görev 10 üzerinden puanlanmıștır. Elde edilen puanlar kriterlerin ağırlıkları ile çarpılarak herbir görevin ergonomik risk faktörü (ERF) Tablo 7'deki gibi belirlenmiștir. Örneğin 2. Görevin ERF'ü $1 * 0,04+8 * 0,13+1 * 0,09=1.18$ olarak hesaplanmıștır.

Tablo 5. Ergonomik kriterlerin ağırlıkları

\begin{tabular}{|c|c|}
\hline Kriterler & A ğırlıklar \\
\hline OÇ & 0,04 \\
\hline AC & 0,13 \\
\hline YÇ & 0,56 \\
\hline MÇ & 0,19 \\
\hline E & 0,09 \\
\hline
\end{tabular}

AHP yönteminde ağırlıklar bulunduktan sonra yapılan işlemlerin tutarlığını gösteren işlemler Tablo 6'da verilmiştir. Görüldüğü üzere tutarlılık oranı (CR)<0,10 olduğundan AHP ile elde edilen sonuç tutarlıdır.

Tablo 6. AHP yöntemi tutarlılığın test edilmesi

\begin{tabular}{ccc}
\hline $\begin{array}{c}\text { Sütun Vektörü } \\
(\mathrm{D})\end{array}$ & $\begin{array}{c}\text { Temel Değer } \\
(\mathrm{E})\end{array}$ & $\begin{array}{c}\text { Lamda } \\
(\lambda)\end{array}$ \\
\hline 0,18 & 5,14 & 5,30 \\
\hline 0,68 & 5,09 & $\begin{array}{c}\text { Tutarlılık İndeksi } \\
(\mathrm{CI})\end{array}$ \\
\hline 3,09 & 5,53 & 0,07 \\
\hline 1,01 & 5,44 & $\begin{array}{c}\text { Tutarlılık Oranı } \\
(\mathrm{CR})\end{array}$ \\
\hline 0,47 & 5,29 & 0,066 \\
\hline
\end{tabular}


Tablo 7. Görevlerin ergonomik açıdan değerlendirilmesi

\begin{tabular}{|c|c|c|c|c|c|c|c|c|c|c|c|c|c|c|}
\hline \multirow{2}{*}{ Kriter } & \multirow{2}{*}{ w } & \multicolumn{13}{|c|}{ GÖREV } \\
\hline & & 1 & 2 & 3 & 4 & 5 & 6 & 7 & 8 & 9 & 10 & 11 & 12 & 13 \\
\hline OÇ & 0,04 & 0 & 1 & 0 & 1 & 0 & 0 & 0 & 4 & 5 & 3 & 0 & 0 & 7 \\
\hline AC & 0,13 & 9 & 8 & 7 & 9 & 4 & 5 & 3 & 6 & 0 & 2 & 2 & 9 & 2 \\
\hline YÇ & 0,56 & 0 & 0 & 0 & 0 & 0 & 3 & 0 & 0 & 0 & 3 & 3 & 1 & 0 \\
\hline $\mathrm{MÇ}$ & 0,19 & 0 & 0 & 0 & 0 & 0 & 0 & 0 & 0 & 0 & 1 & 1 & 0 & 1 \\
\hline$E$ & 0,09 & 1 & 1 & 3 & 0 & 6 & 2 & 7 & 0 & 5 & 2 & 4 & 0 & 0 \\
\hline \multicolumn{2}{|c|}{ ERF } & 1,28 & 1,18 & 1,19 & 1,23 & 1,06 & 2,51 & 1,02 & 0,94 & 0,62 & 2,41 & 2,48 & 1,75 & 0,70 \\
\hline
\end{tabular}

\subsection{Matematiksel Model}

Parametreler;

$\mathrm{i}=\mathrm{i}$ şçi indeksi

$\mathrm{i}=1 . .25$

$\mathrm{j}=\mathrm{iş} \quad$ indeksi

$\mathrm{k}=$ gün indeksi

$\mathrm{k}=1 . .28$

l=zaman dilimi indeksi

$l=1 . .4$

$g_{i j}=i$. personel j.göreve atanabilme durumu $\{0,1\}$

$t_{j l}=j$.görev l. vardiyada yapılma durumu

$w_{\mathrm{jk}}=\mathrm{j}$.görev için $\mathrm{k}$. günde gerekli personel sayısı

karar değişkenleri;

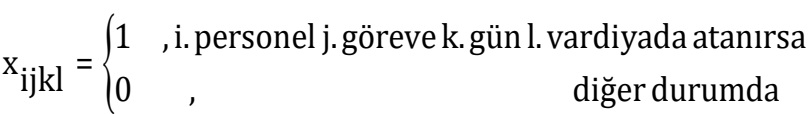

$h_{i k}= \begin{cases}1 & , \text { i. personel k. gün izinli ise } \\ 0 & ,\end{cases}$

$\mathrm{dp}_{\mathrm{ik}}=\mathrm{i}$. personelin $\mathrm{k}$. gündeki pozitif sapma miktarı

$\mathrm{dn}_{\mathrm{ik}}=\mathrm{i}$. personelin $\mathrm{k}$. gündeki negatif sapma miktarı

\section{Kısıtlar;}

1. Kısıt: Bir işçiye, iş süresi başına en fazla bir görevi yerine getirecek şekilde atanabileceğini belirtir.

$\sum_{j=1}^{13} x_{i j k l}<=1$
2. Kısıt: Herhangi bir görev gerçekleştirildiğinde, görevlendirilen görevli sayısı ,en az ihtiyaç kadar olmalıdır.

$\sum_{i=1}^{38} x_{i j k l} \geq w_{j l} \times t_{j k}$

$\forall \mathrm{j}, \mathrm{k}, \mathrm{l}$

3. Kısıt: Herhangi bir işçinin herhangi bir göreve atanıp atanmaması kısıtıdır.

$x_{i j k l} \leq g_{i j}$

$\forall \mathrm{i}, \mathrm{j}, \mathrm{k}, \mathrm{l}$

4. Kısıt: Görevlere görev periyoduna göre personel atanıp atanmaması kısıtıdır.

$x_{i j k l} \leq t_{j l}$

$\forall \mathrm{i}, \mathrm{j}, \mathrm{k}, \mathrm{l}$

5. Kısıt: 13 nolu göreve müdür veya müdür yardımcılarından en az biri atanması kısıtıdır.

$\sum_{i=1}^{2} x_{i 13 k l} \geq 1$

$\forall \mathrm{j}, \mathrm{k}, \mathrm{l}$

6. Kısıt: 4 nolu göreve en az 2 reyon yöneticisi atanması kısıtıdır.

$\sum_{i=3}^{6} x_{i 4 k l} \geq 2$

$\forall \mathrm{j}, \mathrm{k}, \mathrm{l}$

7. Kısit: Tam zamanlı veya idari personellerin haftanın en az 1 gün izinli olması kısıtıdır.

$\sum_{l=1}^{7} h_{i l} \geq 1$

$\mathrm{i}=1,2, . .20$

8. Kısıt: Yarı zamanlı personellerin haftanın en az 2 gün izinli olması kısıtıdır. 
$\sum_{l=1}^{7} h_{i l} \geq 2$

9. Kısıt: Kısmi zamanlı personeller hafta içi çalışmaması kısıtıdır.

$\sum_{l=1}^{5} h_{i l}=5$

10. Kısıt: Her zaman en az 1 temizlik görevlisi (20. ve 29. personel) mağaza bulunmalıdır.

$\sum_{j=1}^{13} x_{20 j k l}+x_{29 j k l} \geq 1$

\section{Hedef kısıtı;}

$\sum_{l=1}^{4} \sum_{j=1}^{13} r i s k_{j} * x_{i j k l}+d n_{i l}+d p_{i l}=5$

$\forall \mathrm{i}, \mathrm{k}$

\section{Amaç fonksiyonu;}

$\operatorname{Min} Z=\sum_{i=1}^{39} \sum_{k=1}^{28} d p_{i k}$

\subsection{Uygulama Sonucu}

Modelin çözümünde "Intel (R) Core (TM) i5-3210 M CPU@2.50 GH” ișlemcisi, 8 GB belleği ve Windows 10 işletim sistemine sahip bilgisayar kullanılmıştır. İlgili verilerin girilmesiyle model ILOG CPLEX Studio IDE programında yazılmış ve CPLEX çözücüsü ile çözülmüştür.Ele alınana problemin mevcut durumu EK-1'de, uygulama sonucu elde edilen çizelgele ise EK2'de gösterilmektedir. Yapılan uygulama sayesinde bütün personellerin eşit ve dengeli olarak vardiyalara atanması sağlanmıştır. Tam zamanlı personellerin en fazla 24 gün, yarı zamanlı personellerin en fazla 20 gün ve yarı zamanlı personellerin de 8 gün çalışması sağlanmıştır. Yine yapılan çalışma ile işçiler arası ergonomik risk unsurlarına göre dengeli arama yapılarak ergonomik risklerin en aza indirilmesi amaçlanmıştır. Örneğin tam zamanlı personellerden 8 numaralı personele EK-2 de bakıldığında 7. Gün için 7,9 ve 10 numaralı görevlere atandığı görülmektedir. Buradan risk faktörü (Tablo 7) hesaplandığında; $1,02 * 1+0,62 * 2+2,41 * 1=4,67$ bulunmuştur. Bir aylık çizelgeye bakıldığında 8 numaralı personelin sapma miktarının 5 'ten büyük olduğu gün bulunmadığından Tablo 8 de "0" olarak hesaplanmıştır. Diğer yandan 8 numaralı personel Ek-1 de gösterilen mevcut durumda 3. Gün 3 ve 6 numaralı görevlere atanmıştır. Buradan risk faktörü $3 * 1,19+1 * 2,51=6,08$ dir. $\mathrm{Bu}$ durumda 3. Gün $6,08-5=1,08$ pozitif sapma meydana gelmiştir. Personelin ay bazında başka bir gün pozitif sapması olmadığından, bir aylık toplam sapma miktarı Tablo 8'de gösterildiği gibi 1,08 olarak bulunmuştur.

Tablo 8. Personellerin 1 aylık sapma miktarlarının kıyaslanması

\begin{tabular}{|l|l|l|l|l|l|l|l|}
\hline \multicolumn{3}{|c|}{ Mevcut Durum } & \multicolumn{4}{|c|}{ Uygulama sonucu } \\
\hline $\mathbf{1}$ & 0,00 & $\mathbf{2 1}$ & 0,00 & $\mathbf{1}$ & 0,00 & $\mathbf{2 1}$ & 0,00 \\
\hline $\mathbf{2}$ & 0,00 & $\mathbf{2 2}$ & 0,00 & $\mathbf{2}$ & 0,00 & $\mathbf{2 2}$ & 0,00 \\
\hline $\mathbf{3}$ & 0,00 & $\mathbf{2 3}$ & 0,00 & $\mathbf{3}$ & 0,00 & $\mathbf{2 3}$ & 0,00 \\
\hline $\mathbf{4}$ & 0,00 & $\mathbf{2 4}$ & 0,00 & $\mathbf{4}$ & 0,00 & $\mathbf{2 4}$ & 0,00 \\
\hline $\mathbf{5}$ & 0,00 & $\mathbf{2 5}$ & 0,00 & $\mathbf{5}$ & 0,00 & $\mathbf{2 5}$ & 0,00 \\
\hline $\mathbf{6}$ & 0,00 & $\mathbf{2 6}$ & 0,00 & $\mathbf{6}$ & 0,00 & $\mathbf{2 6}$ & 0,00 \\
\hline $\mathbf{7}$ & 0,00 & $\mathbf{2 7}$ & 2,40 & $\mathbf{7}$ & 0,00 & $\mathbf{2 7}$ & 0,00 \\
\hline $\mathbf{8}$ & 1,08 & $\mathbf{2 8}$ & 5,00 & $\mathbf{8}$ & 0,00 & $\mathbf{2 8}$ & 0,00 \\
\hline $\mathbf{9}$ & 1,08 & $\mathbf{2 9}$ & 0,00 & $\mathbf{9}$ & 0,00 & $\mathbf{2 9}$ & 0,78 \\
\hline $\mathbf{1 0}$ & 1,08 & $\mathbf{3 0}$ & 0,00 & $\mathbf{1 0}$ & 0,00 & $\mathbf{3 0}$ & 0,00 \\
\hline $\mathbf{1 1}$ & 1,08 & $\mathbf{3 1}$ & 0,00 & $\mathbf{1 1}$ & 0,00 & $\mathbf{3 1}$ & 0,00 \\
\hline $\mathbf{1 2}$ & 2,16 & $\mathbf{3 2}$ & 0,00 & $\mathbf{1 2}$ & 0,00 & $\mathbf{3 2}$ & 0,00 \\
\hline $\mathbf{1 3}$ & 2,16 & $\mathbf{3 3}$ & 0,00 & $\mathbf{1 3}$ & 0,00 & $\mathbf{3 3}$ & 0,00 \\
\hline $\mathbf{1 4}$ & 0,00 & $\mathbf{3 4}$ & 0,00 & $\mathbf{1 4}$ & 0,00 & $\mathbf{3 4}$ & 0,00 \\
\hline $\mathbf{1 5}$ & 0,00 & $\mathbf{3 5}$ & 0,00 & $\mathbf{1 5}$ & 0,00 & $\mathbf{3 5}$ & 0,00 \\
\hline $\mathbf{1 6}$ & 2,28 & $\mathbf{3 6}$ & 0,00 & $\mathbf{1 6}$ & 0,00 & $\mathbf{3 6}$ & 0,00 \\
\hline $\mathbf{1 7}$ & 1,34 & $\mathbf{3 7}$ & 0,00 & $\mathbf{1 7}$ & 0,00 & $\mathbf{3 7}$ & 0,00 \\
\hline $\mathbf{1 8}$ & 1,66 & $\mathbf{3 8}$ & 0,00 & $\mathbf{1 8}$ & 0,00 & $\mathbf{3 8}$ & 0,00 \\
\hline $\mathbf{1 9}$ & 0,00 & $\mathbf{3 9}$ & 0,00 & $\mathbf{1 9}$ & 0,00 & $\mathbf{3 9}$ & 0,00 \\
\hline $\mathbf{2 0}$ & 2,37 & & & $\mathbf{2 0}$ & 1,02 & & \\
\hline toplam sapma & 23,69 & toplam sapma & 1,807 \\
\hline
\end{tabular}

Bunun sonucunda amaç fonksiyonu 1,809 olarak elde edilmiştir. Firmanın mevcut durumda uyguladığ çizelgede personellerin ergonomik risk faktöründen sapması bir ay için 23,69 olarak hesaplanmıştır. Bu durum işletmede daha önce ergonomik faktörlerin dikkate alınmadığını göstermektedir. Görüldüğü üzere yapılan uygulama sonucunda personellerin taşıma, ayakta kalma, eğilme ve yük ile çalışmaları esnasında günlük belirli bir limiti aşmadıkları, bu sayede fiziksel rahatsızlıklarında iyileşmeler olduğu saptanmıştır.

Uygulama sonucunda elde edilen çizelgeye bakıldığında Kısıt 5'de gösterilen mağazada her zaman bir yöneticinin olma kısıtının sağlandığı Ek-2 de görülmektedir. Benzer şekilde Kısıt 6'da belirtilen mağazada her zaman $3,4,5,6$ ve 7 nolu personellerden en az ikisi olması kısıtının sağlandığı Ek-2 de görülmektedir. EK-1'e bakıldığında mağazada görev periyotlarına çok dikkat edilmezken, EK-2' de görüldügü üzere örneğin transfer günlerindeki iş atamalarının kısıt 4 de belirtilen görev periyoduna göre yapıldığı görülmektedir. Diğer yandan EK-2 e bakıldığında 20 ve 29 numaralı temizlik personellerinden en az birinin her zaman mağazada bulunduğu gösterilmektedir. 
Mağaza müdürleri ve çalışanlar ile yapılan görüşmelerde uygulama sonucunda elde edilen çizelgenin uygunluğu tartışılmış ve çıkan sonuçların makul olduğu değerlendirilmiştir.

\section{Sonuç ve Tartışma}

Personel çizelgeleme çalışmaları firmaların performansını etkileyen kritik bir unsurdur. Özellikle emek yoğun işletmelerde personel çizelgeleme daha fazla önemlidir. Çizelgeleme çalışmalarının doğru yapılması personelin hem performansını hem de kişisel motivasyonunu doğrudan etkiler. Bu amaçla Kırıkkale'de tekstil sektöründe faaliyet gösteren bir firmada personel çizelgeleme problemi ele alınmıştır. Firma özellikleri dikkate alınarak 39 personelin bir aylık çizelgelemesi yapılmıştır. Çizelgeleme yapılırken hem personellerin dengeli olarak vardiyalara atanması, hem eşit sayıda izin kullanmaları, hem de ergonomik risk faktörleri açısından dengeli olarak işlere dağıtılmaları sağlanmıştır.

İleride yapılacak çalışmalarda risk faktörleri başka yöntemlerle hesaplanarak çizelgelemeler oluşturulabilir. Yapılan uygulamada sadece fiziksel faktörler dikkate alınmıştır. Personellerin gürültü maruziyetleri, psikolojik etmenler ve zihinsel yoğunluklarını dikkate alan çalışmalar yapılabilir.

\section{Conflict of Interest / Çıkar Çatışması}

Yazarlar tarafından herhangi bir çıkar çatışması beyan edilmemiștir.

No conflict of interest was declared by the authors.

\section{Kaynaklar}

Abbink, E., Fischetti, M., Kroon, L., Timmer, G., Vromans, M., (2005) Reinventing crew scheduling at Netherlands railways, Interfaces 35, 393-401.

Aickelin, U., Burke, E.K., Li, J.P., (2006) Improved squeaky wheel optimisation for driver scheduling, Parallel Problem Solving from Nature - Ppsn Ix, Lecture Notes in Computer Science, 4193, 182191.

Alfares, H.K., (2007) A simulation approach for stochastic employee days-off scheduling, International Journal of Modelling and Simulation 27, 9-15.

Al-Yakoob, S.M., Sherali, H.D., (2008) A column generation approach for an employee scheduling problem with multiple shifts and work locations, Journal of the Operational Research Society 59, 3443.

Asensio-Cuesta, S., Diego-Mas, J. A., Canós-Darós, L., \& Andrés-Romano, C. (2012). A genetic algorithm for the design of job rotation schedules considering ergonomic and competence criteria. The International Journal of Advanced Manufacturing Technology, 60(9), 1161-1174.

Azmat, C.S., Hurlimann, T., Widmer, M., (2004) Mixed integer programming to schedule a single-shift workforce under annualized hours, Annals of Operations Research 128, 199-215.

Bard, J.F., Wan, L., (2006) The task assignment problem for unrestricted movement between workstation groups, Journal of Scheduling 9, 315341.

Beaumont, N. (1997). " Scheduling Staff Using Mixed Integer Programming." European Journal of Operational Research 98, 473-484.

Bektur, G., \& Hasgül, S. (2013). Kıdem seviyelerine göre işgücü çizelgeleme problemi: Hizmet sektöründe bir uygulama. Afyon Kocatepe Üniversitesi İİF Dergisi 11(2), 385-402.

Carnahan, B. J., Redfern, M. S., \& Norman, B. (2000). Designing safe job rotation schedules using optimization and heuristic search. Ergonomics, 43(4), 543-560.

Charnes A., Cooper W.W. (1961). Management Models and Industrial Applications of Linear Programming, Wiley, New York.

Ciritcioğlu, C., Akgün, S., Varlı, E., Eren, T., (2017). Kırıkkale Üniversitesi Güvenlik Görevlileri İçin Vardiya Çizelgeleme Problemine Bir Çözüm Önerisi. Kırıkkale Üniversitesi Uluslararası Mühendislik Araştırma ve Geliştirme Dergisi, 9(2), 1-23.

Dewi, D. S., \& Septiana, T. (2015). Workforce Scheduling Considering Physical and Mental Workload: A Case Study of Domestic Freight Forwarding. Procedia Manufacturing, 4, 445-453.

Körpeli, S., Şahin, B., \& Eren, T. (2011). Hedef Programlama İle Menü Planlamasi: Bir Örnek Uygulama. Erol Kurubaş Uluslararası İlişkiler Düşüncesi ve Dünya Politikasında Değişimi Anlamak, 2(1), 121-142.

Lee S.M. (1972). Goal Programming for Decision Analysis, Auerbach, Philadelphia.

Millet, I., \& Saaty, T. L. (2000). On the relativity of relative measures-accommodating both rank preservation and rank reversals in the AHP. European Journal of Operational Research, 121(1), 205-212.

Narlı, M., (2007). Hemşirelerin Çalışma Vardiyalarının Değerlendirilmesi ve Çizelgelenmesi. Çukurova Üniversitesi Fen Bilimleri Enstitüsü, Yüksek Lisans Tezi.

Özcan, E.C Varlı, E., Eren, T., (2017). Hedef Programlama Yaklaşımı ile Hidroelektrik 
Santrallarda Vardiya Personeli Çizelgeleme. Bilișim Teknolojileri Dergisi, 10(4), 363-370.

Özder, E.H., Varl,, E., Eren, T., (2017). Hedef Programlama Yaklaşımı İle Temizlik Personeli Çizelgeleme Problemi İçin Bir Model Önerisi. Karadeniz Fen Bilimleri Dergisi, 7(2), 114-127.

Rocha, M., Oliveira, J. F., Carravilla, M. A. (2013). Cyclic staff scheduling: optimization models for some real-life problems. Journal of Scheduling, 16(2), 231-242.

Seçkiner, S.U., Kurt, M., (2005). Bütünleşik TurRotasyon Çizelgeleme Yaklaşimi İle İşyükü Minimizasyonu. Gazi Üniversitesi MühendislikMimarlık Fakültesi Dergisi, 20(2).

Otto, A., \& Scholl, A. (2013). Reducing ergonomic risks by job rotation scheduling. OR spectrum, 35(3), 711.

Topaloglu, S., \& Ozkarahan, I. (2003). Implicit optimal tour scheduling with flexible break assignments. Computers \& industrial engineering, 44(1), 75-89.

Varlı E., Eren T., Gencer, M.A., Çetin, S., (2016). Ankara Metrosu M1 Hattındaki Vatmanların Vardiya Saatlerinin Çizelgelenmesi. s. 279-285, 3. Uluslararası Raylı Sistemler Mühendisliği Sempozyumu, Karabük, 13-15 Ekim.

Varlı, E., (2017). İmalat Sektöründe Formenler İçin Vardiya Çizelgeleme Probleminin AHP-Hedef Programlama İle Çözümü. Kırıkkale Üniversitesi Fen Bilimleri Enstitüsü, Yüksek Lisans Tezi.
Varlı, E. Eren, T., (2017). Vardiya Çizelgeleme Problemi ve Bir Örnek Uygulama. International Journal Of Informatics Technologies, 10(2), 185197.

Varlı, E., Alağaş, H.M., Eren, T., Özder, E.H., (2017). Sınav Görevlisi Atama Probleminin Hedef Programlama Yöntemiyle Çözümü. Bilge Uluslararası Fen ve Teknoloji Araștırmaları Dergisi, 1(2), 105-118.

Wind, Y., \& Saaty, T. L. (1980). Marketing applications of the analytic hierarchy process. Management science, 26(7), 641-658.

Wongwien, T., \& Nanthavanij, S. (2012a). Ergonomic workforce scheduling under complex worker limitation and task requirements: Mathematical model and approximation procedure. Songklanakarin Journal of Science and Technology, 34(5), 541-549.

Wongwien, T., \& Nanthavanij, S. (2012b) "Ergonomic Workforce Scheduling for Noisy Workstations with Single or Multiple Workers per Workstation", International Journal of the Computer, the Internet and Management Vol.20 No.3, 34-39.

Yaoyuenyong, K., \& Nanthavanij, S. (2005). Energybased workforce scheduling problem: mathematical model and solution algorithms. ScienceAsia, 31, 383-93. 


\section{EK-1}

\begin{tabular}{|c|c|c|c|c|c|c|c|c|c|c|c|c|c|c|c|c|c|c|c|c|c|c|c|c|c|c|c|c|c|}
\hline i & $\mathbf{l} \backslash \mathbf{k}$ & 1 & 2 & 3 & 4 & 5 & 6 & 7 & 8 & 9 & 10 & 11 & 12 & 13 & 14 & 15 & 16 & 17 & 18 & 19 & 20 & 21 & 22 & 23 & 24 & 25 & 26 & 27 & 28 \\
\hline \multirow{4}{*}{1} & 1 & İ & 13 & 13 & 13 & 13 & 13 & 13 & İ & 13 & 13 & 13 & 13 & 13 & 13 & İ & 13 & 13 & 13 & 13 & 13 & 13 & İ & 13 & 13 & 13 & 13 & 13 & 13 \\
\hline & 2 & İ & 13 & 13 & 13 & 13 & 13 & 13 & İ & 13 & 13 & 13 & 13 & 13 & 13 & $\dot{I}$ & 13 & 13 & 13 & 13 & 13 & 13 & $\dot{I}$ & 13 & 13 & 13 & 13 & 13 & 13 \\
\hline & 3 & İ & 13 & 13 & 13 & 13 & 13 & 13 & İ & 13 & 13 & 13 & 13 & 13 & 13 & İ & 13 & 13 & 13 & 13 & 13 & 13 & İ & 13 & 13 & 13 & 13 & 13 & 13 \\
\hline & 4 & İ & 13 & 13 & 13 & 13 & 13 & 13 & İ & 13 & 13 & 13 & 13 & 13 & 13 & $\dot{I}$ & 13 & 13 & 13 & 13 & 13 & 13 & $\dot{I}$ & 13 & 13 & 13 & 13 & 13 & 13 \\
\hline \multirow{4}{*}{2} & 1 & 13 & İ & 13 & 13 & 13 & 13 & 13 & 13 & $\dot{\mathrm{I}}$ & 13 & 13 & 13 & 13 & 13 & 13 & İ & 13 & 13 & 13 & 13 & 13 & 13 & İ & 13 & 13 & 13 & 13 & 13 \\
\hline & 2 & 13 & İ & 13 & 13 & 13 & 13 & 13 & 13 & İ & 13 & 13 & 13 & 13 & 13 & 13 & İ & 13 & 13 & 13 & 13 & 13 & 13 & İ & 13 & 13 & 13 & 13 & 13 \\
\hline & 3 & 13 & İ & 13 & 13 & 13 & 13 & 13 & 13 & İ & 13 & 13 & 13 & 13 & 13 & 13 & İ & 13 & 13 & 13 & 13 & 13 & 13 & İ & 13 & 13 & 13 & 13 & 13 \\
\hline & 4 & 13 & İ & 13 & 13 & 13 & 13 & 13 & 13 & İ & 13 & 13 & 13 & 13 & 13 & 13 & İ & 13 & 13 & 13 & 13 & 13 & 13 & İ & 13 & 13 & 13 & 13 & 13 \\
\hline \multirow{4}{*}{3} & 1 & 13 & 4 & 4 & İ & 4 & 4 & 4 & 13 & 4 & 4 & İ & 4 & 4 & 4 & 4 & 4 & 4 & İ & 4 & 4 & 4 & 4 & 4 & 4 & 0 & 4 & 4 & İ \\
\hline & 2 & 13 & 4 & 4 & İ & 4 & 4 & 4 & 13 & 4 & 4 & İ & 4 & 4 & 4 & 4 & 4 & 4 & İ & 4 & 4 & 4 & 4 & 4 & 4 & 0 & 4 & 4 & İ \\
\hline & 3 & 13 & 4 & 4 & İ & 4 & 4 & 4 & 13 & 4 & 4 & İ & 4 & 4 & 4 & 4 & 4 & 4 & İ & 4 & 4 & 4 & 4 & 4 & 4 & 0 & 4 & 4 & İ \\
\hline & 4 & 13 & 4 & 4 & I & 4 & 4 & 4 & 13 & 4 & 4 & İ & 4 & 4 & 4 & 4 & 4 & 4 & $\dot{\mathrm{I}}$ & 4 & 4 & 4 & 4 & 4 & 4 & 0 & 4 & 4 & İ \\
\hline \multirow{4}{*}{4} & 1 & İ & 13 & 4 & 4 & 4 & 4 & 4 & İ & 13 & 4 & 4 & 4 & 4 & 4 & İ & 4 & 4 & 4 & 4 & 4 & 4 & İ & 4 & 4 & 4 & 4 & 4 & 4 \\
\hline & 2 & İ & 13 & 4 & 4 & 4 & 4 & 4 & İ & 13 & 4 & 4 & 4 & 4 & 4 & İ & 4 & 4 & 4 & 4 & 4 & 4 & İ & 4 & 4 & 4 & 4 & 4 & 4 \\
\hline & 3 & I & 13 & 4 & 4 & 4 & 4 & 4 & İ & 13 & 4 & 4 & 4 & 4 & 4 & İ & 4 & 4 & 4 & 4 & 4 & 4 & İ & 4 & 4 & 4 & 4 & 4 & 4 \\
\hline & 4 & İ & 13 & 4 & 4 & 4 & 4 & 4 & İ & 13 & 4 & 4 & 4 & 4 & 4 & 1 & 4 & 4 & 4 & 4 & 4 & 4 & İ & 4 & 4 & 4 & 4 & 4 & 4 \\
\hline \multirow{4}{*}{5} & 1 & 7 & 7 & 7 & 7 & 7 & İ & 7 & 7 & 7 & 7 & 7 & $\dot{\mathrm{I}}$ & 7 & 7 & 7 & 7 & 7 & İ & 7 & 7 & 7 & 7 & 7 & İ & 7 & 7 & 7 & 7 \\
\hline & 2 & 8 & 8 & 8 & 8 & 8 & I & 8 & 8 & 8 & 8 & 8 & İ & 8 & 8 & 8 & 8 & 8 & İ & 8 & 8 & 8 & 8 & 8 & İ & 8 & 8 & 8 & 8 \\
\hline & 3 & 9 & 9 & 9 & 9 & 9 & İ & 9 & 9 & 9 & 9 & 9 & $\dot{\mathbf{j}}$ & 9 & 9 & 9 & 9 & 9 & İ & 9 & 9 & 9 & 9 & 9 & İ & 9 & 9 & 9 & 9 \\
\hline & 4 & 10 & 10 & 10 & 10 & 10 & İ & 10 & 10 & 10 & 10 & 10 & $\dot{\mathrm{I}}$ & 10 & 10 & 10 & 10 & 10 & İ & 10 & 10 & 10 & 10 & 10 & İ & 10 & 10 & 10 & 10 \\
\hline \multirow{4}{*}{6} & 1 & 2 & 2 & İ & 2 & 2 & 2 & 2 & 2 & 2 & İ & 2 & 2 & 2 & 2 & 2 & 2 & İ & $\underline{4}$ & 2 & $\underline{L}$ & 2 & 2 & 2 & İ & 2 & 2 & 2 & 2 \\
\hline & 2 & 2 & 2 & $\dot{\mathrm{I}}$ & 2 & 2 & 2 & 2 & 2 & 2 & İ & 2 & 2 & 2 & 2 & 2 & 2 & $\dot{I}$ & 2 & 2 & 2 & 2 & 2 & 2 & İ & 2 & 2 & 2 & 2 \\
\hline & 3 & 2 & 2 & İ & 2 & 2 & 2 & 2 & 2 & 2 & İ & 2 & 2 & 2 & 2 & 2 & 2 & İ & 2 & 2 & 2 & 2 & 2 & 2 & İ & 2 & 2 & 2 & 2 \\
\hline & 4 & 2 & 2 & İ & 2 & 2 & 2 & 2 & 2 & 2 & İ & 2 & 2 & 2 & 2 & 2 & 2 & İ & 2 & 2 & 2 & 2 & 2 & 2 & İ & 2 & 2 & 2 & 2 \\
\hline \multirow{4}{*}{7} & 1 & İ & 4 & 4 & 4 & 4 & 4 & 4 & İ & 4 & 4 & 4 & 4 & 4 & 4 & İ & 13 & 4 & 4 & 4 & 4 & 4 & İ & 13 & 4 & 4 & 4 & 4 & İ \\
\hline & 2 & I & 4 & 4 & 4 & 4 & 4 & 4 & İ & 4 & 4 & 4 & 4 & 4 & 4 & İ & 13 & 4 & 4 & 4 & 4 & 4 & İ & 13 & 4 & 4 & 4 & 4 & İ \\
\hline & 3 & İ & 4 & 4 & 4 & 4 & 4 & 4 & $\dot{\mathrm{I}}$ & 4 & 4 & 4 & 4 & 4 & 4 & İ & 13 & 4 & 4 & 4 & 4 & 4 & İ & 13 & 4 & 4 & 4 & 4 & $\dot{I}$ \\
\hline & 4 & 1 & 4 & 4 & 4 & 4 & 4 & 4 & İ & 4 & 4 & 4 & 4 & 4 & 4 & İ & 13 & 4 & 4 & 4 & 4 & 4 & İ & 13 & 4 & 4 & 4 & 4 & İ \\
\hline \multirow{4}{*}{8} & 1 & 3 & 3 & 3 & 3 & İ & 3 & 3 & 3 & 3 & 3 & 3 & 1 & 3 & 3 & 3 & 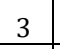 & 3 & 3 & İ & 3 & 3 & 3 & 3 & 3 & İ & 3 & 3 & 3 \\
\hline & 2 & 3 & 3 & 3 & 3 & $\dot{\mathrm{I}}$ & 3 & 3 & 3 & 3 & 3 & 3 & 1 & 3 & 3 & 3 & 3 & 3 & 3 & İ & 3 & 3 & 3 & 3 & 3 & İ & 3 & 3 & 3 \\
\hline & 3 & 3 & 3 & 6 & 3 & 1 & 3 & 3 & 3 & 3 & 3 & 3 & İ & 3 & 3 & 3 & 3 & 3 & 3 & İ & 3 & 3 & 3 & 3 & 3 & İ & 3 & 3 & 3 \\
\hline & 4 & 3 & 3 & 6 & 3 & İ & 3 & 3 & 3 & 3 & 3 & 3 & İ & 3 & 3 & 3 & 3 & 3 & 3 & İ & 3 & 3 & 3 & 3 & 3 & İ & 3 & 3 & 3 \\
\hline \multirow{4}{*}{ G } & 1 & 3 & $\dot{\mathrm{I}}$ & 3 & 3 & 3 & 3 & 3 & 3 & 1 & 3 & 3 & 3 & 3 & 3 & 3 & İ & 3 & 3 & 3 & 3 & 3 & 3 & İ & 3 & 3 & 3 & 3 & 3 \\
\hline & 2 & 3 & İ & 3 & $\Delta$ & 3 & 3 & 3 & 3 & $\dot{\mathbf{I}}$ & 3 & 3 & 3 & 3 & 3 & 3 & İ & 3 & 3 & 3 & 3 & 3 & 3 & İ & 3 & 3 & 3 & 3 & 3 \\
\hline & 3 & 3 & İ & 3 & 3 & 3 & 3 & 3 & 3 & 1 & 6 & 3 & 3 & 3 & 3 & 3 & 1 & 3 & 3 & 3 & 3 & 3 & 3 & İ & 3 & 3 & 3 & 3 & 3 \\
\hline & 4 & 3 & İ & 3 & 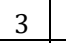 & 3 & 3 & 3 & 3 & 1 & 0 & $J$ & $J$ & $\mathrm{~J}$ & $\mathrm{~J}$ & 5 & İ & 3 & 3 & 3 & 3 & 3 & 3 & İ & 3 & 3 & 3 & 3 & 3 \\
\hline & 1 & 5 & 5 & 5 & $\dot{\mathrm{I}}$ & 5 & 5 & 5 & 5 & 5 & 5 & İ & 5 & 5 & 5 & 5 & 5 & 6 & İ & 5 & 5 & 5 & 5 & 5 & İ & 5 & 5 & 5 & 5 \\
\hline & 2 & 5 & 5 & 5 & İ & 5 & 5 & 5 & 5 & 5 & 5 & 1 & 5 & 5 & 5 & 5 & 5 & 6 & 1 & 5 & 5 & 5 & 5 & 5 & İ & 5 & 5 & 5 & 5 \\
\hline & 3 & 5 & 5 & 5 & $\dot{\mathrm{I}}$ & 5 & 5 & 5 & 5 & 5 & 5 & I & 5 & 5 & 5 & 5 & 5 & 3 & İ & 5 & 5 & 5 & 5 & 5 & İ & 5 & 5 & 5 & 5 \\
\hline & 4 & 5 & 5 & 5 & 1 & 5 & 5 & 5 & 5 & 5 & 5 & $\dot{I}$ & 5 & 5 & 5 & 5 & 5 & 3 & İ & 5 & 5 & 5 & 5 & 5 & $\dot{I}$ & 5 & 5 & 5 & 5 \\
\hline
\end{tabular}




\section{EK-1-devamı}

\begin{tabular}{|c|c|c|c|c|c|c|c|c|c|c|c|c|c|c|c|c|c|c|c|c|c|c|c|c|c|c|c|c|c|}
\hline i & $1 \backslash \mathbf{k}$ & 1 & 2 & 3 & 4 & 5 & 6 & 7 & 8 & 9 & 10 & 11 & 12 & 13 & 14 & 15 & 16 & 17 & 18 & 19 & 20 & 21 & 22 & 23 & 24 & 25 & 26 & 27 & \begin{tabular}{|l|}
28 \\
\end{tabular} \\
\hline \multirow{4}{*}{11} & 1 & $\mathrm{I}$ & 5 & 5 & 5 & 5 & 5 & 5 & $\dot{\mathrm{I}}$ & 5 & 5 & 5 & 5 & 5 & 5 & $\dot{I}$ & 5 & 5 & 5 & 5 & 5 & 5 & $\mathrm{I}$ & 5 & 3 & 5 & 5 & 5 & 5 \\
\hline & 2 & I & 5 & 5 & 5 & 5 & 5 & 5 & I & 5 & 5 & 5 & 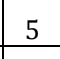 & 5 & 5 & $\dot{\mathrm{I}}$ & 5 & 5 & 5 & 5 & 5 & 5 & İ & 5 & 3 & 5 & 5 & 5 & 5 \\
\hline & 3 & İ & 5 & 5 & 5 & 5 & 5 & 5 & İ & 5 & 5 & 5 & 5 & 5 & 5 & j & 5 & 5 & 5 & 5 & 5 & 5 & İ & 5 & 6 & 5 & 5 & 5 & 5 \\
\hline & 4 & $\dot{\mathrm{I}}$ & 5 & 5 & 5 & 5 & 5 & 5 & $\dot{\mathrm{I}}$ & 5 & 5 & 5 & 5 & 5 & 5 & I & 5 & 5 & 5 & 5 & 5 & 5 & $\dot{I}$ & 5 & 6 & 5 & 5 & 5 & 5 \\
\hline \multirow{4}{*}{12} & 1 & 3 & 3 & 6 & 3 & İ & 3 & 3 & 3 & 3 & 3 & 3 & İ & 3 & 3 & 3 & 3 & 3 & 3 & İ & 3 & 3 & 3 & 3 & 3 & 3 & İ & 3 & 3 \\
\hline & 2 & 3 & 3 & 6 & 3 & I & 3 & 3 & 3 & 3 & 3 & 3 & İ & 3 & 3 & 3 & 3 & 3 & 3 & İ & 3 & 3 & 3 & 3 & 3 & 3 & İ & 3 & 3 \\
\hline & 3 & 3 & 3 & 3 & 3 & $\dot{I}$ & 3 & 3 & 3 & 3 & 3 & 3 & İ & 3 & 3 & 3 & 3 & 3 & 3 & $\dot{\mathrm{I}}$ & 3 & 3 & 3 & 3 & 3 & 3 & $\dot{\mathrm{I}}$ & 3 & 3 \\
\hline & 4 & 3 & 3 & 3 & 3 & İ & 3 & 3 & 3 & 3 & 6 & 3 & I & 3 & 3 & 3 & 3 & 3 & 3 & $\dot{\mathrm{I}}$ & 3 & 3 & 3 & 3 & 3 & 3 & İ & 3 & 3 \\
\hline \multirow{4}{*}{13} & 1 & 5 & 5 & 5 & I & 5 & 5 & 5 & 5 & 5 & 5 & I & 5 & 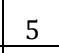 & 5 & 5 & 5 & 6 & İ & 5 & 5 & 5 & 5 & 5 & 6 & $\dot{I}$ & 5 & 5 & 5 \\
\hline & 2 & 5 & 5 & 5 & İ & 5 & 5 & 5 & 5 & 5 & 5 & İ & 5 & 5 & 5 & 5 & 5 & 6 & İ & 5 & 5 & 5 & 5 & 5 & 6 & İ & 5 & 5 & 5 \\
\hline & 3 & 5 & 5 & 5 & I & 5 & 5 & 5 & 5 & 5 & 5 & İ & 5 & 5 & 5 & 5 & 5 & 3 & İ & 5 & 5 & 5 & 5 & 5 & 3 & İ & 5 & 5 & 5 \\
\hline & 4 & 5 & 5 & 5 & I & 5 & 5 & 5 & 5 & 5 & 5 & I & 5 & 5 & 5 & 5 & 5 & 3 & I & 5 & 5 & 5 & 5 & 5 & 3 & $\dot{I}$ & 5 & 5 & 5 \\
\hline \multirow{4}{*}{14} & 1 & 3 & 3 & 3 & 3 & 3 & 3 & 3 & 3 & 3 & 3 & 3 & 3 & 3 & 3 & 5 & 3 & 3 & 3 & 3 & 3 & 3 & 3 & 3 & 3 & 3 & 3 & 3 & 3 \\
\hline & 2 & 3 & 3 & 3 & 3 & 3 & 3 & 3 & 3 & 3 & 3 & 3 & 3 & 3 & 3 & 3 & 3 & 3 & 3 & 3 & 3 & 3 & 3 & 3 & 3 & 3 & 3 & 3 & 3 \\
\hline & 3 & 3 & 3 & 3 & 3 & 3 & 3 & 3 & 3 & 3 & 3 & 3 & 3 & 3 & 3 & 3 & 3 & 3 & 3 & 3 & 3 & 3 & 3 & 3 & 3 & 3 & 3 & 3 & 3 \\
\hline & 4 & 3 & 3 & 3 & 3 & 3 & 3 & 3 & 3 & 3 & 3 & 3 & 3 & 3 & 3 & 3 & 3 & 3 & 3 & 3 & 3 & 3 & 3 & 3 & 3 & 3 & 3 & 3 & 3 \\
\hline \multirow{4}{*}{1} & 1 & 5 & 5 & 5 & 5 & 5 & 5 & 5 & 5 & 5 & 5 & İ & 5 & 5 & 5 & 5 & 5 & 5 & İ & 5 & 5 & 5 & 5 & 5 & 5 & I & 5 & 5 & 5 \\
\hline & 2 & 5 & 5 & 5 & 5 & 5 & 5 & 5 & 5 & 5 & 5 & İ & 5 & 5 & 5 & 5 & 5 & 5 & I & 5 & 5 & 5 & 5 & 5 & 5 & $\dot{I}$ & 5 & 5 & 5 \\
\hline & 3 & 5 & 5 & 5 & 5 & 5 & 5 & 5 & 5 & 5 & 5 & $\dot{\mathrm{I}}$ & 5 & 5 & 5 & 5 & 5 & 5 & İ & 5 & 5 & 5 & 5 & 5 & 5 & I & 5 & 5 & 5 \\
\hline & 4 & 5 & 5 & 5 & 5 & 5 & 5 & 5 & 5 & 5 & 5 & I & 5 & 5 & 5 & 5 & 5 & 5 & I & 5 & 5 & 5 & 5 & 5 & 5 & I & 5 & 5 & 5 \\
\hline \multirow{4}{*}{16} & 1 & 7 & 7 & 6 & 7 & $\dot{I}$ & 7 & 7 & 7 & 7 & 6 & 7 & İ & 7 & 7 & 7 & 7 & 6 & 7 & $\dot{I}$ & 7 & 7 & 7 & 7 & 6 & 7 & I & 7 & 7 \\
\hline & 2 & 7 & 7 & 6 & 7 & İ & 7 & 7 & 7 & 7 & 6 & 7 & İ & 7 & 7 & 7 & 7 & 6 & 7 & $\dot{I}$ & 7 & 7 & 7 & 7 & 6 & 7 & I & 7 & 7 \\
\hline & 3 & 7 & 7 & 6 & 7 & İ & 7 & 7 & 7 & 7 & 6 & 7 & İ & 7 & 7 & 7 & 7 & 6 & 7 & $\dot{\mathrm{I}}$ & 7 & 7 & 7 & 7 & 6 & 7 & İ & 7 & 7 \\
\hline & 4 & 7 & 7 & 7 & 7 & i & 7 & 7 & 7 & 7 & 7 & 7 & İ & 7 & 7 & 7 & 7 & 1 & 7 & İ & 7 & 7 & 7 & 7 & 7 & 7 & İ & 7 & 7 \\
\hline \multirow{4}{*}{17} & 1 & 1 & 1 & I & 1 & \begin{tabular}{|l|} 
\\
\end{tabular} & 1 & 1 & 1 & 1 & İ & 1 & 1 & $\dot{\mathrm{I}}$ & 1 & 1 & 1 & $\dot{\mathrm{I}}$ & 1 & 1 & 1 & 1 & 1 & 1 & $\dot{I}$ & 1 & 1 & 1 & $\dot{\mathrm{I}}$ \\
\hline & 2 & 1 & 1 & $\mathrm{I}$ & 1 & 1 & 1 & 1 & 1 & 1 & İ & 1 & 1 & I & 1 & 1 & 1 & İ & \begin{tabular}{|l|} 
\\
\end{tabular} & \begin{tabular}{|l|} 
\\
\end{tabular} & \begin{tabular}{|c|} 
\\
\end{tabular} & 1 & 1 & 1 & $\dot{I}$ & 1 & 1 & 1 & İ \\
\hline & 3 & 4 & 4 & I & 4 & 4 & 4 & 4 & 4 & 4 & İ & 4 & 4 & İ & 4 & 4 & 4 & $\mathrm{I}$ & 1 & 1 & 1 & 1 & 1 & 1 & $\dot{I}$ & 1 & 1 & 1 & I \\
\hline & 4 & 4 & 4 & $\dot{I}$ & 4 & \begin{tabular}{|l|} 
\\
\end{tabular} & 4 & 4 & 4 & 4 & i & \begin{tabular}{|l|} 
\\
\end{tabular} & \begin{tabular}{|l|} 
\\
\end{tabular} & $\dot{\mathrm{I}}$ & 4 & 4 & 4 & $\dot{\mathrm{I}}$ & 1 & 1 & 1 & 1 & 1 & 1 & $\dot{I}$ & 1 & 1 & 1 & $\dot{\mathrm{I}}$ \\
\hline \multirow{4}{*}{1} & 1 & İ & 1 & 1 & 1 & 1 & 1 & 1 & İ & 1 & 1 & 1 & 1 & 1 & 1 & I & 4 & 4 & 4 & 4 & 4 & 4 & İ & 4 & 4 & 4 & 4 & 4 & İ \\
\hline & 2 & İ & 1 & 1 & 1 & 1 & 1 & 1 & $\dot{\mathrm{I}}$ & 1 & 1 & 1 & 1 & 1 & 1 & i & 4 & 4 & 4 & 4 & 4 & 4 & $\dot{I}$ & 4 & 4 & 4 & 4 & 4 & $\dot{I}$ \\
\hline & 3 & ì & 1 & 1 & 1 & \begin{tabular}{|l|} 
\\
\end{tabular} & 1 & 1 & $\dot{\mathrm{I}}$ & 1 & 1 & \begin{tabular}{|l|} 
\\
\end{tabular} & 1 & 1 & 1 & I & 1 & 1 & 1 & 1 & 1 & 1 & $\dot{I}$ & 1 & 1 & 1 & 1 & 1 & $\dot{\mathrm{I}}$ \\
\hline & 4 & $\mathrm{I}$ & 1 & 1 & 1 & 1 & 1 & 1 & $\dot{I}$ & 1 & 1 & 1 & 1 & 1 & 1 & i & 1 & 1 & 1 & 1 & 1 & 1 & $\dot{I}$ & 1 & 1 & 1 & 1 & 1 & $\dot{I}$ \\
\hline \multirow{4}{*}{1} & 1 & 7 & 7 & $\mathrm{I}$ & 7 & 7 & 7 & 7 & 7 & 7 & $\dot{I}$ & 7 & 7 & 7 & 7 & 7 & 7 & İ & 7 & 7 & 7 & 7 & 7 & 7 & $\dot{I}$ & 7 & 7 & 7 & 7 \\
\hline & 2 & 7 & 7 & $\mathrm{I}$ & 7 & 7 & 7 & 7 & 7 & 7 & İ & 7 & 7 & 7 & 7 & 7 & 7 & $\dot{\mathrm{I}}$ & 7 & 7 & 7 & 7 & 7 & 7 & $\dot{I}$ & 7 & 7 & 7 & 7 \\
\hline & 3 & 7 & 7 & I & 7 & 7 & 7 & 7 & 7 & 7 & İ & 7 & 7 & 7 & 7 & 7 & 7 & I & 7 & 7 & 7 & 7 & 7 & 7 & $\dot{I}$ & 7 & 7 & 7 & 7 \\
\hline & 4 & 7 & 7 & İ & 7 & 7 & 7 & 7 & 7 & 7 & $\dot{\mathrm{I}}$ & 7 & 7 & 7 & 7 & 7 & 7 & $\mathrm{I}$ & 7 & 7 & 7 & 7 & 7 & 7 & $\dot{I}$ & 7 & 7 & 7 & 7 \\
\hline \multirow{4}{*}{2} & 1 & 11 & $\dot{\mathrm{I}}$ & 12 & 12 & 12 & 12 & 12 & 12 & $\dot{I}$ & 12 & 12 & 12 & 12 & 12 & 12 & $\dot{\mathrm{I}}$ & 12 & 12 & 12 & 12 & 12 & 12 & İ & 12 & 12 & 12 & 12 & 12 \\
\hline & $\underline{L}$ & 12 & $\dot{\mathrm{I}}$ & 12 & 12 & 12 & 12 & 12 & 12 & I & 12 & 12 & 12 & 12 & 12 & 12 & I & 12 & 12 & 12 & 12 & 12 & 12 & I & 12 & 12 & 12 & 12 & 12 \\
\hline & 3 & 12 & $\dot{\mathrm{I}}$ & 12 & 12 & 12 & 12 & 12 & 12 & $\dot{I}$ & 12 & 12 & 12 & 12 & 12 & 12 & $\mathrm{I}$ & 12 & 12 & 12 & 12 & 12 & 12 & İ & 12 & 12 & 12 & 12 & 12 \\
\hline & 4 & 12 & I & 12 & 12 & 12 & 12 & 12 & 12 & İ & 12 & 12 & 12 & 12 & 12 & 12 & I & 12 & 12 & 12 & 12 & 12 & 12 & I & 12 & 12 & 12 & 12 & 12 \\
\hline
\end{tabular}




\section{EK-1-devamı}

\begin{tabular}{|c|c|c|c|c|c|c|c|c|c|c|c|c|c|c|c|c|c|c|c|c|c|c|c|c|c|c|c|c|c|}
\hline i & $1 \backslash \mathbf{k}$ & 1 & 2 & 3 & 4 & 5 & 6 & 7 & 8 & 9 & 10 & 11 & 12 & 13 & 14 & 15 & 16 & 17 & 18 & 19 & 20 & 21 & 22 & 23 & 24 & 25 & 26 & 27 & \begin{tabular}{|l|}
28 \\
\end{tabular} \\
\hline \multirow{4}{*}{21} & 1 & İ & 3 & 3 & 3 & İ & 3 & 3 & $\dot{I}$ & 3 & 3 & 3 & İ & 3 & 3 & İ & 3 & 3 & 3 & İ & 3 & 3 & İ & 3 & 3 & 3 & I & 3 & 3 \\
\hline & 2 & I & 3 & 3 & 3 & I & 3 & 3 & I & 3 & 3 & 3 & $\dot{I}$ & 3 & 3 & İ & 3 & 3 & 3 & $\dot{I}$ & 3 & 3 & $\dot{I}$ & 3 & 3 & 3 & I & 3 & 3 \\
\hline & 3 & $\dot{\mathrm{I}}$ & 3 & 3 & 3 & I & 3 & 3 & $\dot{I}$ & 3 & 3 & 3 & İ & 3 & 3 & I & 3 & 3 & 3 & $\dot{\mathrm{I}}$ & 3 & 3 & $\dot{\mathrm{I}}$ & 3 & 3 & 3 & I & 3 & 3 \\
\hline & 4 & $\dot{\mathrm{I}}$ & 3 & 3 & 3 & İ & 3 & 3 & $\dot{\mathrm{I}}$ & 3 & 3 & 3 & İ & 3 & 3 & İ & 3 & 3 & 3 & $\dot{\mathrm{I}}$ & 3 & 3 & İ & 3 & 3 & 3 & I & 3 & 3 \\
\hline \multirow{4}{*}{22} & 1 & 5 & 5 & İ & İ & 5 & 5 & 5 & 5 & 5 & İ & İ & 5 & 5 & 5 & 5 & 5 & $\dot{\mathbf{I}}$ & İ & 5 & 5 & 5 & 5 & 5 & İ & İ & 5 & 5 & 5 \\
\hline & 2 & 5 & 5 & $\dot{\mathrm{I}}$ & $\dot{I}$ & 5 & 5 & 5 & 5 & 5 & $\mathrm{i}$ & $\mathrm{I}$ & 5 & 5 & 5 & 5 & 5 & $\dot{I}$ & $\mathrm{I}$ & 5 & 5 & 5 & 5 & 5 & I & $\dot{\mathrm{I}}$ & 5 & 5 & 5 \\
\hline & 3 & 5 & 5 & $\dot{\mathrm{I}}$ & $\dot{I}$ & 5 & 5 & 5 & 5 & 5 & İ & $\dot{\mathrm{I}}$ & 5 & 5 & 5 & 5 & 5 & $\dot{I}$ & $\dot{I}$ & 5 & 5 & 5 & 5 & 5 & $\dot{\mathrm{I}}$ & $\dot{I}$ & 5 & 5 & 5 \\
\hline & 4 & 5 & 5 & I & $\dot{\mathrm{I}}$ & 5 & 5 & 5 & 5 & 5 & $\mathrm{i}$ & İ & 5 & 5 & 5 & 5 & 5 & $\mathrm{I}$ & $\mathrm{I}$ & 5 & 5 & 5 & 5 & 5 & I & $\dot{I}$ & 5 & 5 & 5 \\
\hline \multirow{4}{*}{23} & 1 & $\mathrm{I}$ & 3 & 3 & i & 3 & 3 & 3 & I & 3 & 3 & I & 3 & 3 & 3 & 1 & 3 & 3 & I & 3 & 3 & 3 & İ & 3 & 3 & I & 3 & 3 & 3 \\
\hline & 2 & $\dot{I}$ & 3 & 3 & $\dot{\mathrm{I}}$ & 3 & 3 & 3 & $\dot{\mathrm{I}}$ & 3 & 3 & İ & 3 & 3 & 3 & I & 3 & 3 & $\dot{\mathrm{I}}$ & 3 & 3 & 3 & $\dot{I}$ & 3 & 3 & $\dot{I}$ & 3 & 3 & 3 \\
\hline & 3 & İ & 3 & 3 & İ & 3 & 3 & 3 & $\dot{\mathrm{I}}$ & 3 & 3 & I & 3 & 3 & 3 & I & 3 & 3 & İ & 3 & 3 & 3 & İ & 3 & 3 & $\dot{\mathrm{I}}$ & 3 & 3 & 3 \\
\hline & 4 & $\dot{\mathrm{I}}$ & 3 & 3 & $\dot{I}$ & 3 & 3 & 3 & $\mathrm{I}$ & 3 & 3 & $\dot{I}$ & 3 & 3 & 3 & i & 3 & 3 & $\dot{I}$ & 3 & 3 & 3 & I & 3 & 3 & $\dot{I}$ & 3 & 3 & 3 \\
\hline \multirow{4}{*}{24} & 1 & 5 & $\dot{\mathrm{I}}$ & $\dot{\mathrm{I}}$ & 5 & 5 & 5 & 5 & 5 & I & I & 5 & 5 & 5 & 5 & 5 & $\dot{\mathrm{I}}$ & $\dot{\mathrm{I}}$ & 5 & 5 & 5 & 5 & 5 & $\dot{\mathrm{I}}$ & $\dot{\mathrm{I}}$ & 5 & 5 & 5 & 5 \\
\hline & 2 & 5 & İ & İ & 5 & 5 & 5 & 5 & 5 & İ & İ & 5 & 5 & 5 & 5 & 5 & $\dot{I}$ & İ & 5 & 5 & 5 & 5 & 5 & İ & İ & 5 & 5 & 5 & 5 \\
\hline & 3 & 5 & İ & İ & 5 & 5 & 5 & 5 & 5 & I & I & 5 & 5 & 5 & 5 & 5 & İ & İ & 5 & 5 & 5 & 5 & 5 & İ & İ & 5 & 5 & 5 & 5 \\
\hline & 4 & 5 & $\dot{I}$ & İ & 5 & 5 & 5 & 5 & 5 & İ & İ & 5 & 5 & 5 & 5 & 5 & İ & İ & 5 & 5 & 5 & 5 & 5 & İ & İ & 5 & 5 & 5 & 5 \\
\hline \multirow{4}{*}{25} & 1 & 7 & $\dot{I}$ & 7 & $\dot{\mathrm{I}}$ & 7 & 7 & 7 & 7 & I & 7 & $\mathrm{I}$ & 7 & 7 & 7 & İ & 7 & $\dot{I}$ & 7 & 7 & 7 & 7 & İ & 7 & İ & 7 & 7 & 7 & $\dot{I}$ \\
\hline & 2 & 8 & I & 8 & $\dot{I}$ & 8 & 8 & 8 & 8 & I & 8 & i & 8 & 8 & 8 & I & 8 & İ & 8 & 8 & 8 & 8 & $\dot{\mathrm{I}}$ & 8 & $\dot{I}$ & 8 & 8 & 8 & İ \\
\hline & 3 & 9 & $\dot{\mathrm{I}}$ & 9 & $\dot{\mathrm{I}}$ & 9 & 9 & 9 & 9 & İ & 9 & $\dot{\mathrm{I}}$ & 9 & 9 & 9 & İ & 9 & İ & 9 & 9 & 9 & 9 & İ & 9 & I & 9 & 9 & 9 & I \\
\hline & 4 & 10 & $\dot{\mathrm{I}}$ & 10 & $\dot{I}$ & 10 & 10 & 10 & 10 & İ & 10 & I & 10 & 10 & 10 & I & 10 & $\mathrm{i}$ & 10 & 10 & 10 & 10 & İ & 10 & $\dot{I}$ & 10 & 10 & 10 & $\dot{I}$ \\
\hline \multirow{4}{*}{26} & 1 & 10 & 10 & İ & 10 & I & 10 & 10 & 10 & 10 & I & 10 & İ & 10 & 10 & 10 & İ & 10 & I & 10 & 10 & 10 & 10 & İ & 10 & $\dot{I}$ & 10 & 10 & 10 \\
\hline & 2 & 9 & 9 & İ & 9 & I & 9 & 9 & 9 & 9 & I & 9 & İ & 9 & 9 & 9 & I & 9 & I & 9 & 9 & 9 & 9 & İ & 9 & $\mathrm{I}$ & 9 & 9 & 9 \\
\hline & 3 & 8 & 8 & I & 8 & I & 8 & 8 & 8 & 8 & I & 8 & $\dot{I}$ & 8 & 8 & 8 & I & 8 & $\dot{I}$ & 8 & 8 & 8 & 8 & I & 8 & $\dot{I}$ & 8 & 8 & 8 \\
\hline & 4 & 7 & 7 & I & 7 & i & 7 & 7 & 7 & 7 & I & 7 & İ & 7 & 7 & 7 & İ & 7 & İ & 7 & 7 & 7 & 7 & $\dot{\mathrm{I}}$ & 7 & $\dot{I}$ & 7 & 7 & 7 \\
\hline \multirow{4}{*}{27} & 1 & $\dot{I}$ & 1 & $\dot{I}$ & $\dot{I}$ & 1 & 1 & 1 & $\mathrm{i}$ & 1 & 1 & İ & 1 & 1 & 1 & $\mathrm{I}$ & 1 & 1 & $\dot{I}$ & 1 & 1 & 1 & I & 1 & 1 & $\dot{\mathrm{I}}$ & 1 & 1 & 1 \\
\hline & 2 & I & 1 & $\dot{\mathrm{I}}$ & $\dot{\mathrm{I}}$ & 1 & 1 & 1 & $\dot{\mathrm{I}}$ & 1 & 1 & I & 1 & 1 & 1 & I & 1 & 1 & I & 1 & 1 & 1 & İ & 1 & 1 & $\mathrm{I}$ & 1 & 1 & 1 \\
\hline & 3 & $\dot{\mathrm{I}}$ & 1 & $\dot{I}$ & $\dot{\mathrm{I}}$ & 1 & 1 & 1 & $\dot{I}$ & 1 & 1 & $\mathrm{I}$ & 1 & 1 & 1 & İ & 1 & 1 & İ & 1 & 1 & 1 & İ & 1 & 1 & $\dot{I}$ & 1 & 1 & 1 \\
\hline & 4 & $\dot{\mathrm{I}}$ & 1 & I & $\dot{I}$ & 1 & 1 & 1 & $\dot{\mathrm{I}}$ & 1 & 1 & I & 1 & 1 & 1 & i & 1 & 1 & $\dot{I}$ & 1 & 1 & 1 & İ & 1 & 1 & I & 1 & 1 & 1 \\
\hline \multirow{4}{*}{2} & 1 & 9 & $\dot{I}$ & 9 & 9 & I & 9 & 9 & 9 & İ & 9 & 9 & İ & 9 & 9 & 9 & I & 9 & 9 & İ & 9 & 9 & 9 & I & 9 & 9 & İ & 9 & 9 \\
\hline & 2 & 9 & İ & 9 & 9 & İ & 9 & 9 & 9 & I & 9 & 9 & $\dot{I}$ & 9 & 9 & 9 & İ & 9 & 9 & $\dot{I}$ & 9 & 9 & 9 & I & 9 & 9 & İ & 9 & 9 \\
\hline & 3 & 9 & İ & 9 & 9 & İ & 9 & 9 & 9 & I & 9 & 9 & İ & 9 & 9 & 9 & $\mathrm{i}$ & 9 & 9 & $\dot{I}$ & 9 & 9 & 9 & İ & 9 & 9 & İ & 9 & 9 \\
\hline & 4 & 9 & $\dot{\mathrm{I}}$ & 9 & 9 & $\mathrm{I}$ & 9 & 9 & 9 & I & 9 & 9 & $\dot{I}$ & 9 & 9 & 9 & $\mathrm{I}$ & 9 & 9 & $\dot{\mathrm{I}}$ & 9 & 9 & 9 & $\dot{\mathrm{I}}$ & 9 & 9 & İ & 9 & 9 \\
\hline \multirow{4}{*}{2} & 1 & $\dot{\mathrm{I}}$ & $\mathrm{i}$ & $\dot{\mathrm{I}}$ & $\dot{I}$ & i & 3 & 4 & $\mathrm{I}$ & i & i & I & $\dot{I}$ & 3 & 4 & \begin{tabular}{|l|}
$\mathrm{I}$ \\
\end{tabular} & $\mid \dot{I}$ & $\mid \dot{I}$ & $\mid \mathrm{I}$ & $\dot{\mathrm{I}}$ & 3 & 4 & I & $\dot{\mathrm{I}}$ & $\dot{\mathrm{I}}$ & $\dot{I}$ & İ & 3 & 4 \\
\hline & 2 & İ & $\dot{\mathrm{I}}$ & İ & $\dot{\mathrm{I}}$ & I & 3 & 4 & İ & I & I & $\dot{I}$ & İ & 3 & 4 & I & İ & İ & İ & İ & 3 & 4 & $\dot{I}$ & $\dot{I}$ & I & $\mathrm{I}$ & İ & 3 & 4 \\
\hline & 3 & $\dot{\mathrm{I}}$ & $\dot{I}$ & $\dot{\mathrm{I}}$ & $\dot{I}$ & I & 3 & 4 & $\dot{\mathrm{I}}$ & İ & İ & $\dot{\mathrm{I}}$ & $\dot{I}$ & 3 & 4 & $\dot{I}$ & $\mathrm{I}$ & $\dot{\mathrm{I}}$ & $\dot{I}$ & $\dot{\mathrm{I}}$ & 3 & 4 & $\dot{I}$ & $\dot{\mathrm{I}}$ & $\dot{\mathrm{I}}$ & I & İ & 3 & 4 \\
\hline & 4 & $\dot{\mathrm{I}}$ & $\dot{I}$ & $\dot{\mathrm{I}}$ & $\dot{\mathrm{I}}$ & İ & 3 & 4 & $\dot{\mathrm{I}}$ & İ & İ & $\dot{\mathrm{I}}$ & $\dot{I}$ & 3 & 4 & $\dot{\mathrm{I}}$ & $\dot{\mathrm{I}}$ & $\dot{\mathrm{I}}$ & $\dot{\mathrm{I}}$ & $\dot{\mathrm{I}}$ & 3 & 4 & $\dot{\mathrm{I}}$ & $\dot{\mathrm{I}}$ & $\dot{\mathrm{I}}$ & İ & İ & 3 & 4 \\
\hline \multirow{4}{*}{3} & 1 & $\dot{\mathrm{I}}$ & $\dot{I}$ & $\dot{\mathrm{I}}$ & $\dot{\mathrm{I}}$ & $\dot{I}$ & 3 & 4 & $\dot{I}$ & I & I & I & $\dot{I}$ & 3 & 4 & i & $\dot{\mathrm{I}}$ & $\dot{\mathrm{I}}$ & i & $\dot{\mathrm{I}}$ & 3 & 4 & I & $\dot{\mathrm{I}}$ & $\dot{\mathrm{I}}$ & $\mathrm{i}$ & İ & 3 & 4 \\
\hline & 2 & İ & İ & İ & İ & I & 3 & 4 & $\dot{\mathrm{I}}$ & I & I & $\mathrm{I}$ & İ & 3 & 4 & I & I & $\dot{I}$ & I & İ & 3 & 4 & \begin{tabular}{|l|} 
\\
\end{tabular} & $\dot{\mathrm{I}}$ & İ & İ & $\dot{I}$ & 3 & 4 \\
\hline & 3 & $\dot{\mathrm{I}}$ & $\dot{\mathrm{I}}$ & $\dot{\mathrm{I}}$ & $\dot{\mathrm{I}}$ & $\dot{\mathrm{I}}$ & 3 & 4 & $\dot{\mathrm{I}}$ & $\dot{\mathrm{I}}$ & I & $\dot{I}$ & $\dot{\mathrm{I}}$ & 3 & 4 & $\dot{\mathrm{I}}$ & $\dot{\mathrm{I}}$ & $\dot{\mathrm{I}}$ & $\dot{\mathrm{I}}$ & $\dot{\mathrm{I}}$ & 3 & 4 & $\dot{\mathrm{I}}$ & $\dot{\mathrm{I}}$ & $\dot{\mathrm{I}}$ & $\mathrm{i}$ & İ & 3 & 4 \\
\hline & 4 & $\dot{\mathrm{I}}$ & $\dot{\mathrm{I}}$ & 1 & İ & I & 3 & 4 & I & $\mathrm{I}$ & I & İ & $\dot{\mathrm{I}}$ & 3 & 4 & $\mathrm{I}$ & $\mid \dot{\mathrm{I}}$ & $\mathrm{I}$ & İ & | & 3 & 4 & \begin{tabular}{|l|l|} 
\\
\end{tabular} & İ & $\dot{I}$ & $\dot{I}$ & & 3 & 4 \\
\hline
\end{tabular}




\section{EK-1-devamı}

\begin{tabular}{|c|c|c|c|c|c|c|c|c|c|c|c|c|c|c|c|c|c|c|c|c|c|c|c|c|c|c|c|c|c|}
\hline i & $1 \backslash \mathbf{k}$ & 1 & 2 & 3 & 4 & 5 & 6 & 7 & 8 & 9 & 10 & 11 & 12 & 13 & 14 & 15 & 16 & 17 & 18 & 19 & 20 & 21 & 22 & 23 & 24 & 25 & 26 & 27 & 28 \\
\hline \multirow{4}{*}{31} & 1 & $\dot{\mathrm{I}}$ & $\dot{I}$ & I & I & $\dot{I}$ & 3 & 4 & I & \begin{tabular}{|l|}
$\mathrm{I}$ \\
\end{tabular} & I & İ & İ & 3 & 4 & İ & I & $\dot{I}$ & I & I & 3 & 4 & I & $\dot{I}$ & I & $\dot{\mathrm{I}}$ & I & 3 & 4 \\
\hline & 2 & İ & İ & I & I & ì & 3 & 4 & I & İ & I & I & I & 3 & 4 & İ & İ & İ & I & I & 3 & 4 & I & I & I & İ & i & 3 & 4 \\
\hline & 3 & İ & İ & I & I & I & 3 & 4 & $\dot{\mathrm{I}}$ & İ & $\dot{I}$ & İ & j & 3 & 4 & İ & İ & İ & İ & İ & 3 & 4 & İ & İ & İ & $\dot{I}$ & $\dot{\mathrm{I}}$ & 3 & 4 \\
\hline & 4 & $\dot{\mathrm{I}}$ & $\dot{I}$ & I & I & $\dot{I}$ & 3 & 4 & I & \begin{tabular}{|l|}
$\mathrm{I}$ \\
\end{tabular} & I & I & $\dot{\mathrm{I}}$ & 3 & 4 & I & I & $\dot{\mathrm{I}}$ & I & $\dot{\mathrm{I}}$ & 3 & 4 & I & I & I & $\dot{\mathrm{I}}$ & İ & 3 & 4 \\
\hline \multirow{4}{*}{32} & 1 & İ & İ & İ & İ & İ & 3 & 4 & İ & İ & İ & İ & İ & 3 & 4 & İ & I & İ & İ & İ & 3 & 4 & İ & İ & İ & İ & İ & 3 & 4 \\
\hline & 2 & I & $\dot{I}$ & I & I & I & 3 & 4 & I & $\dot{\mathrm{I}}$ & $\mathrm{i}$ & I & İ & 3 & 4 & I & $\dot{I}$ & I & I & I & 3 & 4 & I & $\dot{I}$ & I & $\dot{\mathrm{I}}$ & $\dot{\mathrm{I}}$ & 3 & 4 \\
\hline & 3 & $\dot{\mathrm{I}}$ & $\dot{I}$ & İ & I & İ & 3 & 4 & İ & I & İ & $\dot{\mathrm{I}}$ & İ & 3 & 4 & İ & İ & İ & İ & İ & 3 & 4 & İ & I & İ & $\mathrm{I}$ & İ & 3 & 4 \\
\hline & 4 & $\dot{I}$ & İ & I & I & İ & 3 & 4 & İ & I & İ & I & I & 3 & 4 & I & I & İ & İ & İ & 3 & 4 & İ & İ & I & İ & I & 3 & 4 \\
\hline \multirow{4}{*}{33} & 1 & $\dot{\mathrm{I}}$ & $\dot{I}$ & I & I & $\dot{I}$ & 3 & 4 & I & I & I & $\mathrm{I}$ & $\dot{I}$ & 3 & 4 & İ & $\dot{I}$ & $\dot{I}$ & $\dot{I}$ & $\dot{I}$ & 3 & 4 & $\dot{I}$ & $\dot{I}$ & $\dot{I}$ & $\mathrm{I}$ & I & 3 & 4 \\
\hline & 2 & İ & İ & İ & I & İ & 3 & 4 & İ & I & İ & $\dot{\mathrm{I}}$ & İ & 3 & 4 & İ & İ & İ & İ & İ & 3 & 4 & İ & İ & İ & İ & İ & 3 & 4 \\
\hline & 3 & İ & İ & İ & İ & İ & 3 & 4 & İ & İ & I & I & İ & 3 & 4 & İ & İ & İ & İ & İ & 3 & 4 & İ & İ & İ & İ & İ & 3 & 4 \\
\hline & 4 & $\dot{\mathrm{I}}$ & $\dot{I}$ & $\dot{I}$ & $\mathrm{I}$ & $\dot{I}$ & 3 & 4 & $\mathrm{I}$ & I & $\mathrm{i}$ & $\mathrm{I}$ & I & 3 & 4 & I & $\dot{I}$ & $\dot{I}$ & $\dot{I}$ & $\dot{I}$ & 3 & 4 & I & $\dot{I}$ & $\dot{I}$ & $\dot{I}$ & I & 3 & 4 \\
\hline \multirow{4}{*}{34} & 1 & İ & İ & I & I & I & 3 & 4 & İ & İ & İ & $\dot{\mathrm{I}}$ & İ & 3 & 4 & İ & İ & İ & İ & İ & 3 & 4 & $\dot{I}$ & $\dot{I}$ & İ & $\dot{\mathrm{I}}$ & İ & 3 & 4 \\
\hline & 2 & İ & İ & İ & İ & I & 3 & 4 & İ & I & İ & İ & İ & 3 & 4 & I & I & İ & İ & İ & 3 & 4 & İ & $\dot{I}$ & İ & $\dot{\mathrm{I}}$ & İ & 3 & 4 \\
\hline & 3 & İ & İ & İ & I & I & 3 & 4 & İ & I & \begin{tabular}{|l}
$\mathrm{I}$ \\
\end{tabular} & İ & İ & 3 & 4 & I & I & İ & I & İ & 3 & 4 & İ & İ & İ & İ & I & 3 & 4 \\
\hline & 4 & $\dot{\mathrm{I}}$ & $\dot{I}$ & I & I & I & 3 & 4 & İ & \begin{tabular}{|l|}
$\mathrm{I}$ \\
\end{tabular} & İ & I & $\dot{\mathrm{I}}$ & 3 & 4 & İ & $\dot{I}$ & $\dot{I}$ & $\dot{\mathrm{I}}$ & $\dot{\mathrm{I}}$ & 3 & 4 & $\dot{I}$ & $\dot{I}$ & $\dot{\mathrm{I}}$ & $\dot{\mathrm{I}}$ & $\mathrm{i}$ & 3 & 4 \\
\hline \multirow{4}{*}{35} & 1 & İ & $\dot{I}$ & İ & I & I & 3 & 4 & İ & İ & İ & İ & İ & 3 & 4 & İ & İ & İ & İ & İ & 3 & 4 & İ & $\dot{I}$ & İ & İ & I & 3 & 4 \\
\hline & 2 & $\dot{\mathrm{I}}$ & $\dot{I}$ & $\dot{\mathrm{I}}$ & İ & $\dot{I}$ & 3 & 4 & $\dot{\mathrm{I}}$ & $\dot{I}$ & I & I & İ & 3 & 4 & İ & İ & İ & İ & İ & 3 & 4 & İ & İ & İ & $\dot{\mathrm{I}}$ & İ & 3 & 4 \\
\hline & 3 & İ & $\dot{I}$ & I & I & I & 3 & 4 & İ & İ & İ & İ & İ & 3 & 4 & I & I & I & I & İ & 3 & 4 & İ & İ & İ & $\dot{I}$ & İ & 3 & 4 \\
\hline & 4 & $\dot{I}$ & $\mathrm{I}$ & İ & I & I & 3 & 4 & İ & II & İ & I & $\dot{\mathrm{I}}$ & 3 & 4 & $\mathrm{i}$ & I & İ & $\mathrm{i}$ & İ & 3 & 4 & İ & İ & İ & $\dot{\mathrm{I}}$ & $\dot{\mathrm{I}}$ & 3 & 4 \\
\hline \multirow{4}{*}{36} & 1 & $\dot{\mathrm{I}}$ & $\dot{I}$ & $\dot{I}$ & İ & $\dot{I}$ & 4 & 3 & $\dot{I}$ & $\dot{I}$ & İ & I & İ & 4 & 3 & İ & $\dot{I}$ & $\dot{\mathrm{I}}$ & $\dot{\mathrm{I}}$ & $\dot{I}$ & 4 & 3 & I & I & I & I & I & 4 & 3 \\
\hline & 2 & İ & $\dot{I}$ & I & I & I & 4 & 3 & İ & İ & İ & İ & İ & 4 & 3 & I & İ & İ & I & İ & 4 & 3 & İ & İ & İ & $\dot{I}$ & İ & 4 & 3 \\
\hline & 3 & $\dot{I}$ & $\dot{I}$ & $\dot{\mathrm{I}}$ & I & I & 4 & 3 & I & İ & İ & İ & İ & 4 & 3 & İ & $\dot{I}$ & $\dot{I}$ & $\dot{I}$ & $\dot{I}$ & 4 & 3 & $\dot{I}$ & $\dot{I}$ & İ & I & İ & 4 & 3 \\
\hline & 4 & $\dot{I}$ & $\dot{I}$ & İ & I & I & 4 & 3 & I & $\dot{\mathrm{I}}$ & İ & İ & $\dot{\mathrm{I}}$ & 4 & 3 & $\dot{I}$ & İ & $\dot{\mathrm{I}}$ & İ & $\dot{I}$ & 4 & 3 & İ & $\dot{I}$ & $\dot{I}$ & I & $\dot{I}$ & 4 & 3 \\
\hline \multirow{4}{*}{3} & 1 & $\dot{\mathrm{I}}$ & $\dot{I}$ & İ & İ & I & 4 & 3 & I & I & I & İ & $\dot{\mathrm{I}}$ & 4 & 3 & $\dot{\mathrm{I}}$ & $\dot{I}$ & $\dot{\mathrm{I}}$ & $\dot{\mathrm{I}}$ & $\dot{\mathrm{I}}$ & 4 & 3 & $\dot{I}$ & $\dot{I}$ & $\dot{\mathrm{I}}$ & $\dot{I}$ & $\dot{\mathrm{I}}$ & 4 & 3 \\
\hline & 2 & İ & İ & I & I & I & 4 & 3 & İ & İ & İ & İ & İ & 4 & 3 & I & I & İ & I & $\dot{I}$ & 4 & 3 & İ & I & I & $\mathrm{I}$ & İ & 4 & 3 \\
\hline & 3 & I & $\dot{I}$ & I & I & I & 4 & 3 & I & \begin{tabular}{|l|}
$\mathrm{I}$ \\
\end{tabular} & İ & I & İ & 4 & 3 & I & I & I & I & I & 4 & 3 & I & I & I & $\dot{\mathrm{I}}$ & I & 4 & 3 \\
\hline & 4 & $\dot{\mathrm{I}}$ & $\dot{I}$ & I & I & I & 4 & 3 & I & I & İ & I & $\dot{\mathrm{I}}$ & 4 & 3 & İ & $\dot{\mathrm{I}}$ & $\dot{\mathrm{I}}$ & $\dot{\mathrm{I}}$ & $\dot{\mathrm{I}}$ & 4 & 3 & $\dot{I}$ & $\dot{I}$ & $\dot{\mathrm{I}}$ & $\dot{I}$ & $\dot{\mathrm{I}}$ & 4 & 3 \\
\hline \multirow{4}{*}{38} & 1 & $\dot{I}$ & $\dot{I}$ & $\dot{\mathrm{I}}$ & I & I & 4 & 3 & I & İ & İ & $\dot{\mathrm{I}}$ & $\dot{I}$ & 4 & 3 & $\dot{\mathrm{I}}$ & $\dot{I}$ & $\dot{I}$ & $\dot{I}$ & $\dot{I}$ & 4 & 3 & $\dot{I}$ & $\dot{I}$ & $\dot{I}$ & I & İ & 4 & 3 \\
\hline & 2 & İ & İ & I & I & I & 4 & 3 & I & İ & İ & İ & İ & 4 & 3 & İ & İ & İ & İ & İ & 4 & 3 & İ & $\dot{I}$ & İ & I & İ & 4 & 3 \\
\hline & 3 & $\mathrm{I}$ & $\dot{I}$ & I & I & i & 4 & 3 & $\dot{I}$ & I & I & i & $\dot{I}$ & 4 & 3 & $\mathrm{i}$ & I & I & I & $\mathrm{i}$ & 4 & 3 & $\dot{I}$ & $\dot{I}$ & I & $\mathrm{I}$ & $\dot{\mathrm{I}}$ & 4 & $\underline{3}$ \\
\hline & 4 & $\mathrm{I}$ & $\dot{I}$ & I & I & I & 4 & 3 & I & I & I & $\mathrm{I}$ & $\mathrm{I}$ & 4 & 3 & $\dot{I}$ & $\dot{I}$ & $\dot{I}$ & $\dot{I}$ & $\dot{I}$ & 4 & 3 & $\dot{I}$ & $\dot{I}$ & $\dot{I}$ & $\mathrm{i}$ & $\dot{I}$ & 4 & 3 \\
\hline \multirow{4}{*}{3} & 1 & $\dot{\mathrm{I}}$ & $\dot{I}$ & I & I & I & 4 & 3 & I & \begin{tabular}{|l|}
$\mathrm{I}$ \\
\end{tabular} & I & I & $\dot{\mathrm{I}}$ & 4 & 3 & $\dot{\mathrm{I}}$ & $\dot{I}$ & $\dot{I}$ & $\dot{I}$ & $\dot{I}$ & 4 & 3 & $\dot{I}$ & $\dot{I}$ & $\dot{\mathrm{I}}$ & $\mathrm{i}$ & $\dot{I}$ & 4 & 3 \\
\hline & 2 & $\mathrm{I}$ & $\dot{I}$ & I & I & $\mathrm{I}$ & 4 & 3 & $\dot{I}$ & $\dot{\mathrm{I}}$ & I & I & $\dot{\mathrm{I}}$ & 4 & 3 & i & I & I & I & İ & 4 & 3 & $\dot{I}$ & $\dot{\mathrm{I}}$ & I & $\mathrm{i}$ & İ & 4 & 3 \\
\hline & 3 & $\dot{\mathrm{I}}$ & I & $\dot{\mathrm{I}}$ & 1 & I & 4 & 3 & $\dot{I}$ & $\dot{\mathrm{I}}$ & $\dot{\mathrm{I}}$ & $\dot{\mathrm{I}}$ & $\dot{\mathrm{I}}$ & 4 & 3 & İ & $\dot{I}$ & $\dot{I}$ & İ & $\dot{I}$ & 4 & 3 & $\dot{I}$ & $\dot{I}$ & $\dot{\mathrm{I}}$ & $\dot{\mathrm{I}}$ & I & 4 & 3 \\
\hline & 4 & $\dot{\mathrm{I}}$ & $\dot{I}$ & $\dot{\mathrm{I}}$ & İ & I & 4 & 3 & $\dot{\mathrm{I}}$ & $\dot{I}$ & $\dot{I}$ & $\dot{\mathrm{I}}$ & $\dot{\mathrm{I}}$ & 4 & 3 & İ & $\dot{I}$ & İ & İ & $\dot{I}$ & 4 & 3 & $\dot{I}$ & I & $\dot{\mathrm{I}}$ & i & $\mid \dot{I}$ & 4 & 3 \\
\hline
\end{tabular}




\section{EK-2}

\begin{tabular}{|c|c|c|c|c|c|c|c|c|c|c|c|c|c|c|c|c|c|c|c|c|c|c|c|c|c|c|c|c|c|}
\hline $\mathbf{i}$ & $1 \backslash \mathrm{k}$ & 1 & 2 & 3 & 4 & 5 & 6 & 7 & 8 & 9 & 10 & 11 & 12 & 13 & 14 & 15 & 16 & 17 & 18 & 19 & 20 & 21 & 22 & 23 & 24 & 25 & 26 & 27 & 28 \\
\hline \multirow{4}{*}{1} & 1 & 13 & 13 & 13 & $\dot{\mathrm{I}}$ & 13 & 2 & 13 & 13 & 13 & 13 & 13 & İ & 13 & 13 & 13 & 13 & 13 & 13 & 13 & İ & 13 & 13 & 13 & 13 & 13 & İ & 13 & 13 \\
\hline & 2 & 13 & 13 & 13 & $\dot{\mathrm{I}}$ & 13 & 13 & 13 & 8 & 13 & 13 & 13 & $\dot{\mathrm{I}}$ & 13 & 13 & 13 & 13 & 13 & 13 & 13 & $\dot{\mathrm{I}}$ & 13 & 13 & 13 & 13 & 13 & İ & 13 & 13 \\
\hline & 3 & 13 & 13 & 13 & İ & 13 & 13 & 13 & 13 & 13 & 13 & 13 & İ & 13 & 13 & 13 & 13 & 13 & 13 & 13 & İ & 13 & 13 & 13 & 13 & 13 & İ & 13 & 13 \\
\hline & 4 & 13 & 13 & 13 & İ & 13 & 13 & 13 & 13 & 13 & 13 & 13 & İ & 13 & 13 & 13 & 13 & 13 & 13 & 13 & İ & 13 & 13 & 13 & 13 & 13 & İ & 13 & 13 \\
\hline \multirow{4}{*}{2} & 1 & 4 & 4 & 4 & 13 & 4 & 4 & $\dot{\mathrm{I}}$ & 8 & 2 & 4 & 13 & 13 & 4 & İ & 4 & 13 & 4 & 13 & İ & 13 & 4 & 4 & 4 & 2 & İ & 13 & 4 & 13 \\
\hline & 2 & 4 & 4 & 4 & 13 & 4 & 4 & İ & 13 & 4 & 4 & 13 & 13 & 13 & İ & 4 & 4 & 4 & 4 & İ & 13 & 13 & 8 & 4 & 4 & İ & 13 & 4 & 4 \\
\hline & 3 & 4 & 4 & 4 & 13 & 13 & 4 & İ & 4 & 4 & 4 & 4 & 13 & 4 & İ & 4 & 4 & 4 & 4 & İ & 13 & 4 & 4 & 4 & 4 & $\dot{\mathrm{I}}$ & 13 & 4 & 13 \\
\hline & 4 & 4 & 13 & 13 & 13 & 13 & 13 & İ & 4 & 4 & 13 & 13 & 13 & 4 & $\dot{\mathrm{I}}$ & 4 & 13 & 4 & 13 & İ & 13 & 4 & 4 & 4 & 4 & İ & 13 & 4 & 4 \\
\hline \multirow{4}{*}{3} & 1 & $\dot{\mathrm{I}}$ & $T$ & 6 & 4 & $T$ & 1 & 4 & 4 & 13 & 4 & 4 & 4 & İ & 13 & İ & 4 & 4 & 4 & 13 & 13 & 4 & İ & 13 & 1 & 4 & 13 & 4 & 13 \\
\hline & 2 & İ & 4 & 13 & 4 & 4 & 4 & 4 & 4 & 4 & 4 & 4 & 13 & İ & 4 & İ & 4 & 4 & 13 & 4 & 4 & 4 & İ & 13 & 4 & 13 & 4 & 4 & 13 \\
\hline & 3 & İ & 4 & 13 & 13 & 13 & 4 & 4 & 4 & 1 & 4 & 13 & 13 & İ & 4 & İ & 4 & 4 & 13 & 4 & 4 & 13 & İ & 13 & 4 & 13 & 13 & 4 & 4 \\
\hline & 4 & İ & 13 & 13 & 13 & 13 & 13 & 13 & 13 & 13 & 4 & 4 & 4 & İ & 13 & İ & 4 & 4 & 4 & 13 & 4 & 4 & İ & 13 & 4 & 13 & 4 & 13 & 13 \\
\hline \multirow{4}{*}{4} & 1 & 4 & 4 & 1 & 4 & İ & 1 & 4 & 4 & 4 & 6 & İ & 13 & 13 & 4 & İ & 4 & 6 & 1 & 4 & 4 & 13 & 1 & İ & 6 & 13 & 4 & 13 & 4 \\
\hline & 2 & 4 & 4 & 4 & 4 & İ & 13 & 13 & 4 & 13 & 13 & İ & 4 & 4 & 13 & İ & 13 & 13 & 1 & 13 & 13 & 4 & 4 & İ & 13 & 4 & 13 & 13 & 1 \\
\hline & 3 & 4 & 13 & 4 & 13 & İ & 13 & 13 & 4 & 13 & 13 & İ & 4 & 13 & 13 & İ & 13 & 13 & 13 & 13 & 13 & 1 & 13 & İ & 13 & 4 & 4 & 13 & 13 \\
\hline & 4 & 13 & 13 & 4 & 13 & İ & 13 & 13 & 4 & 2 & 13 & $\dot{I}$ & 13 & 13 & 4 & İ & 4 & 13 & 4 & 4 & 13 & 13 & 1 & İ & 13 & 4 & 13 & 4 & 1 \\
\hline \multirow{4}{*}{5} & 1 & 1 & İ & 1 & 4 & 4 & 2 & 4 & İ & 4 & 1 & 4 & 4 & 4 & 4 & 4 & $\dot{I}$ & 1 & 4 & 4 & 4 & 2 & 4 & 4 & 1 & 4 & 4 & İ & 4 \\
\hline & 2 & 4 & $\dot{\mathrm{I}}$ & 4 & 4 & 4 & 4 & 4 & İ & 1 & 4 & 4 & 4 & 4 & 4 & 4 & İ & 1 & 4 & 4 & 4 & 1 & 4 & 4 & 2 & 4 & 4 & İ & 4 \\
\hline & 3 & 4 & İ & 4 & 4 & 4 & 4 & 4 & İ & 4 & 4 & 4 & 4 & 4 & 4 & 4 & İ & 2 & 4 & 4 & 4 & 4 & 4 & 4 & 4 & 4 & 4 & İ & 4 \\
\hline & 4 & 4 & $\dot{\mathrm{I}}$ & 4 & 4 & 4 & 4 & 4 & I & 4 & 4 & 4 & 4 & 4 & 4 & 4 & İ & 2 & 1 & 4 & 4 & 2 & 4 & 4 & 4 & 4 & 4 & İ & 4 \\
\hline \multirow{4}{*}{6} & 1 & 8 & 9 & 9 & 9 & 9 & 9 & İ & 9 & 9 & 9 & 9 & 9 & İ & 9 & 8 & İ & 9 & 10 & 9 & 9 & 1 & 8 & 9 & 9 & 10 & 9 & İ & 9 \\
\hline & 2 & 8 & 9 & 0 & 9 & 9 & 9 & İ & 10 & 9 & 0 & 10 & 9 & İ & 0 & 8 & İ & 9 & 9 & 9 & 9 & İ & 9 & 10 & 9 & 9 & 9 & İ & 9 \\
\hline & 3 & 9 & 9 & 9 & 9 & 9 & 9 & İ & 9 & 10 & 9 & 9 & 9 & İ & 10 & 10 & İ & 9 & 9 & 9 & 9 & İ & 9 & 9 & 9 & 9 & 9 & İ & 10 \\
\hline & 4 & 10 & 10 & 10 & 10 & 10 & 10 & $\dot{\mathrm{I}}$ & 9 & 9 & 10 & 9 & 10 & $\dot{\mathfrak{I}}$ & 9 & 9 & $\dot{I}$ & 10 & 9 & 10 & 10 & İ & 0 & 9 & 10 & 9 & 10 & İ & 9 \\
\hline \multirow{4}{*}{7} & 1 & 1 & 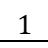 & 1 & 1 & 1 & İ & 1 & 2 & $\dot{\mathrm{I}}$ & 1 & 2 & 2 & 2 & 2 & 2 & 2 & $\dot{I}$ & 2 & 2 & 2 & 2 & 2 & 2 & İ & 2 & 2 & 2 & 2 \\
\hline & 2 & 1 & 1 & 1 & 1 & 1 & İ & 1 & 1 & $\dot{\mathrm{I}}$ & 1 & 1 & 1 & 1 & 1 & 1 & 1 & İ & 1 & 1 & 1 & 1 & 1 & 1 & İ & 1 & 1 & 1 & 1 \\
\hline & 3 & 2 & 2 & 2 & 2 & 2 & İ & 2 & 1 & İ & 2 & 1 & 1 & 1 & 1 & 1 & 1 & $\dot{I}$ & 1 & 1 & 1 & $l_{1}$ & 1 & 1 & İ & 1 & 1 & 1 & 1 \\
\hline & 4 & 2 & 2 & 2 & 2 & 2 & İ & 2 & 2 & I & 2 & 2 & 2 & 2 & 2 & 2 & 2 & İ & 2 & 2 & 2 & 2 & 2 & 2 & İ & 2 & 2 & 2 & 2 \\
\hline \multirow{4}{*}{8} & 1 & 1 & 1 & 3 & $\dot{I}$ & 5 & 7 & 1 & İ & 9 & 5 & 3 & 10 & 1 & 5 & 5 & 5 & 5 & 5 & İ & 10 & 7 & 1 & 5 & 3 & 5 & 9 & 7 & 1 \\
\hline & 2 & 9 & 1 & 6 & İ & 7 & 9 & 1 & İ & 10 & 9 & 9 & 9 & 9 & 9 & 1 & 9 & 6 & 9 & İ & 7 & 7 & İ & 5 & 6 & 5 & 1 & 7 & 9 \\
\hline & 3 & 9 & 5 & 9 & $\dot{\mathrm{I}}$ & 9 & 9 & 1 & İ & 9 & 9 & 10 & 9 & 9 & 5 & 7 & 10 & 9 & 9 & İ & 9 & 1 & İ & 5 & 9 & 5 & 3 & 5 & 9 \\
\hline & 1 & 10 & 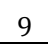 & 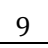 & $\dot{I}$ & 1 & 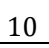 & 3 & 1 & $\Delta$ & 10 & 9 & 1 & 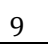 & 12 & 7 & 9 & 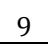 & 10 & 1 & 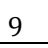 & 1 & İ & 1 & 9 & 12 & 5 & 12 & 10 \\
\hline & 1 & İ & 3 & 5 & 7 & 1 & 1 & 1 & 3 & 3 & 5 & 9 & 1 & 7 & $\dot{\mathrm{I}}$ & 1 & 9 & 3 & 9 & 5 & 7 & 1 & 10 & 9 & 5 & 1 & İ & 9 & 1 \\
\hline & 2 & İ & 3 & 6 & 9 & 1 & 9 & 1 & 1 & 9 & 9 & 5 & 3 & 1 & $\dot{I}$ & İ & 3 & 6 & 3 & 7 & 1 & 1 & 9 & 9 & 6 & 10 & İ & 9 & 7 \\
\hline & 3 & İ & 3 & 9 & 9 & 1 & 9 & 5 & 5 & 1 & 9 & 12 & 3 & 9 & İ & İ & 9 & 9 & 10 & 9 & 1 & 9 & 9 & 10 & 9 & 9 & İ & 1 & 9 \\
\hline & 4 & 1 & 5 & 9 & 10 & 5 & 10 & 7 & 1 & 1 & 10 & 3 & 5 & 1 & İ & $\dot{I}$ & 10 & 9 & 9 & 5 & 1 & 1 & 7 & 5 & 9 & 9 & İ & 10 & 5 \\
\hline & 1 & 1 & S & 5 & 1 & 5 & İ & 5 & 3 & 1 & 3 & 1 & İ & 9 & 10 & 3 & 1 & 6 & 1 & 10 & 7 & 5 & 7 & İ & 6 & 9 & İ & 10 & 7 \\
\hline & 2 & 3 & 9 & 9 & 1 & 9 & İ & 9 & 1 & 7 & 6 & 9 & İ & 10 & 9 & 9 & 1 & 7 & 5 & 3 & 9 & 12 & 10 & İ & 7 & 3 & İ & 1 & 5 \\
\hline & $\mathrm{J}$ & 3 & 3 & 3 & 3 & 9 & İ & 9 & 9 & 1 & 9 & 9 & İ & 7 & 1 & 3 & İ & 9 & 3 & 9 & 10 & 9 & 9 & İ & 9 & 9 & İ & 9 & 1 \\
\hline & 4 & 5 & 10 & 10 & 5 & 10 & $\dot{I}$ & 10 & 1 & 1 & 9 & 10 & İ & 9 & 9 & 1 & $\dot{\mathrm{I}}$ & 9 & 5 & 9 & 9 & 3 & 9 & İ & 9 & 10 & İ & 9 & 1 \\
\hline
\end{tabular}




\section{EK-2 devamı}

\begin{tabular}{|c|c|c|c|c|c|c|c|c|c|c|c|c|c|c|c|c|c|c|c|c|c|c|c|c|c|c|c|c|c|}
\hline $\mathbf{i}$ & $\mathbf{l} \backslash \mathbf{k}$ & 1 & 2 & 3 & 4 & 5 & 6 & 7 & 8 & 9 & 10 & 11 & 12 & 13 & 14 & 15 & 16 & 17 & 18 & 19 & 20 & 21 & 22 & 23 & 24 & 25 & 26 & 27 & 28 \\
\hline \multirow{4}{*}{11} & 1 & 3 & 3 & 5 & 1 & 1 & İ & 1 & İ & 7 & 3 & 5 & 7 & 1 & 7 & 1 & 1 & 5 & $\dot{I}$ & 3 & 9 & 3 & 1 & 10 & 3 & 9 & 9 & İ & 1 \\
\hline & 2 & 9 & 3 & 6 & 3 & 3 & $\dot{\mathrm{I}}$ & 9 & İ & 3 & 6 & 12 & 1 & 9 & 7 & 9 & 3 & 6 & $\dot{I}$ & 1 & 9 & 9 & 5 & 3 & 6 & 9 & 3 & $\dot{I}$ & 9 \\
\hline & 3 & 9 & 3 & 9 & 3 & 3 & İ & 9 & İ & 9 & 9 & 9 & 3 & 9 & 7 & 9 & 1 & 9 & İ & 3 & 7 & 12 & 3 & 9 & 9 & 10 & 12 & İ & 1 \\
\hline & 4 & 10 & 3 & 9 & 5 & 5 & İ & 10 & İ & 5 & 9 & 1 & 5 & 10 & 7 & 10 & 3 & 9 & $\dot{I}$ & 3 & 7 & 7 & 5 & 9 & 9 & 3 & 1 & $\dot{\mathrm{I}}$ & 3 \\
\hline \multirow{4}{*}{12} & 1 & 1 & 1 & 1 & 5 & 5 & $\dot{I}$ & 1 & 5 & $\dot{I}$ & 3 & 10 & 9 & 5 & 9 & 3 & 10 & 5 & $\dot{I}$ & 7 & 9 & 3 & İ & 1 & 5 & 5 & 1 & 1 & 9 \\
\hline & 2 & 3 & 3 & 9 & 5 & 5 & İ & 9 & 3 & İ & 3 & 9 & 10 & 1 & 9 & 1 & 9 & 6 & $\dot{\mathrm{I}}$ & 5 & 7 & 9 & İ & 1 & 9 & 1 & 1 & 1 & 10 \\
\hline & 3 & 7 & 5 & 9 & 7 & 9 & İ & 9 & 9 & $\dot{I}$ & 9 & 7 & 9 & 9 & 1 & 5 & 9 & 9 & $\dot{I}$ & 12 & 9 & 9 & İ & 1 & 9 & 1 & 3 & 7 & 9 \\
\hline & 4 & 9 & 9 & 10 & 9 & 12 & İ & 10 & 12 & İ & 12 & 9 & 3 & 3 & 10 & 1 & 5 & 9 & İ & 5 & 12 & 10 & İ & 7 & 10 & 5 & 3 & 7 & 5 \\
\hline \multirow{4}{*}{13} & 1 & 3 & İ & 1 & 5 & 1 & 1 & 1 & 7 & 3 & 1 & 1 & 9 & 7 & $\dot{I}$ & 3 & İ & 5 & 3 & 9 & 9 & 9 & 1 & $\dot{\mathrm{I}}$ & 5 & 7 & 1 & 9 & 9 \\
\hline & 2 & 3 & İ & 1 & 9 & 3 & 1 & 1 & 3 & 9 & 9 & 3 & 7 & 12 & İ & 3 & İ & 6 & 3 & 9 & 10 & 3 & 5 & İ & 6 & 5 & 9 & 10 & 5 \\
\hline & 3 & 5 & İ & 3 & 9 & 3 & 5 & 1 & 3 & 9 & 9 & 9 & 5 & 7 & İ & 9 & İ & 9 & 1 & 10 & 3 & 1 & 5 & İ & 9 & 1 & 10 & 9 & 7 \\
\hline & 4 & 9 & İ & 5 & 10 & 5 & 7 & 9 & 5 & 10 & 10 & 5 & 3 & 5 & İ & 3 & İ & 9 & 3 & 1 & 9 & 1 & 5 & İ & 9 & 1 & 9 & 3 & 1 \\
\hline \multirow{4}{*}{14} & 1 & İ & 7 & 5 & 5 & 3 & 5 & 1 & 10 & İ & 6 & 9 & 3 & 5 & 1 & 5 & 5 & 3 & 7 & 1 & I & 10 & 9 & 3 & 3 & 5 & 5 & 9 & İ \\
\hline & 2 & İ & 9 & 6 & 9 & 9 & 9 & 1 & 9 & İ & 7 & 5 & 5 & 7 & 9 & 1 & 1 & 9 & 5 & 3 & İ & 1 & 5 & 9 & 6 & 3 & 7 & 9 & İ \\
\hline & 3 & İ & 9 & 9 & 9 & 9 & 9 & 3 & 9 & İ & 9 & 3 & 3 & 1 & 7 & 3 & 5 & 9 & 7 & 3 & İ & 9 & 5 & 9 & 9 & 3 & 5 & 10 & İ \\
\hline & 4 & İ & 10 & 9 & 10 & 10 & 10 & 5 & 5 & $\dot{I}$ & 9 & 12 & 1 & 1 & 5 & 3 & 3 & 10 & 12 & 1 & İ & 9 & 1 & 3 & 9 & 1 & 1 & 1 & İ \\
\hline \multirow{4}{*}{15} & 1 & 3 & 1 & 6 & 3 & İ & 1 & 1 & 1 & 5 & 6 & 7 & 5 & 9 & $\dot{\mathrm{I}}$ & 10 & 9 & 1 & $\dot{\mathrm{I}}$ & 5 & 1 & 9 & 3 & İ & 1 & 1 & 10 & 7 & 7 \\
\hline & 2 & 3 & 3 & 7 & 3 & $\dot{I}$ & 1 & 7 & 5 & 3 & 9 & 9 & 7 & 9 & $\dot{I}$ & 7 & 5 & 9 & $\dot{I}$ & 9 & 1 & 9 & 3 & $\dot{I}$ & 9 & 3 & 9 & 5 & 9 \\
\hline & 3 & 5 & 3 & 9 & 3 & İ & 5 & 9 & 3 & 5 & 9 & 5 & 7 & 10 & İ & 9 & 5 & 9 & İ & 7 & 9 & 10 & 3 & İ & 9 & 5 & 9 & 1 & 3 \\
\hline & 4 & 9 & 3 & 9 & 5 & İ & 9 & 12 & 7 & 7 & 9 & 1 & 3 & 1 & İ & 9 & 3 & 10 & İ & 12 & 1 & 7 & 5 & İ & 10 & 3 & 9 & 1 & 12 \\
\hline \multirow{4}{*}{16} & 1 & 1 & 5 & 3 & 5 & 1 & 1 & İ & 1 & 1 & 5 & 3 & İ & 1 & 1 & İ & İ & 5 & 5 & 9 & 1 & 1 & 3 & 3 & 3 & İ & 3 & 1 & 1 \\
\hline & 2 & 3 & 9 & 6 & 5 & 1 & 1 & İ & 9 & 5 & 6 & 5 & İ & 1 & 7 & İ & İ & 6 & 7 & 12 & 1 & 7 & 7 & 1 & 9 & $\dot{\mathrm{I}}$ & 9 & 1 & 1 \\
\hline & 3 & 9 & 9 & 9 & 7 & 9 & 1 & $\dot{I}$ & 7 & 5 & 9 & 5 & İ & 5 & 1 & İ & İ & 9 & 1 & 1 & 9 & 1 & 9 & 9 & 9 & İ & 3 & 5 & 1 \\
\hline & 4 & 12 & 10 & 9 & 12 & 12 & 7 & İ & 3 & 9 & 9 & 5 & İ & 1 & 1 & İ & İ & 9 & 3 & 1 & 1 & 7 & 12 & 3 & 10 & İ & 5 & 3 & 7 \\
\hline \multirow{4}{*}{17} & 1 & 5 & İ & 6 & 1 & 1 & 1 & 1 & 9 & $\dot{I}$ & 3 & 5 & 9 & 9 & 5 & 5 & 5 & 7 & 5 & $\dot{\mathrm{I}}$ & 1 & 9 & İ & 5 & 5 & 9 & 1 & 9 & 10 \\
\hline & 2 & 9 & $\dot{\mathrm{I}}$ & 9 & 3 & 9 & 1 & 1 & 9 & İ & 6 & 1 & 9 & 7 & 1 & 5 & 10 & 9 & 9 & İ & 9 & 1 & İ & 7 & 9 & 12 & 10 & 1 & 7 \\
\hline & 3 & 9 & İ & 9 & 9 & 9 & 1 & 1 & 1 & $\dot{I}$ & 9 & 1 & 10 & 1 & 1 & 9 & 9 & 9 & 12 & İ & 1 & 1 & İ & 3 & 9 & 3 & 9 & 7 & 9 \\
\hline & 4 & 10 & İ & 9 & 12 & 10 & 9 & 7 & 10 & İ & 9 & 7 & 1 & 5 & 1 & 12 & 9 & 10 & 5 & İ & 12 & 12 & İ & 3 & 12 & 3 & 9 & 1 & 9 \\
\hline \multirow{4}{*}{18} & 1 & 1 & İ & 6 & 1 & 3 & 1 & 7 & 3 & 1 & 3 & 9 & 1 & İ & 9 & İ & 3 & 3 & 9 & 5 & 1 & 1 & 3 & 9 & 3 & 3 & 1 & İ & 9 \\
\hline & 2 & 5 & İ & 7 & 3 & 3 & 1 & 9 & 3 & 1 & 6 & 1 & 1 & İ & 10 & İ & 5 & 6 & 10 & 5 & 5 & 10 & 9 & 9 & 6 & 9 & 5 & İ & 1 \\
\hline & 3 & 5 & İ & 9 & 3 & 5 & 3 & 9 & 5 & 3 & 9 & 3 & 5 & İ & 9 & İ & 3 & 9 & 5 & 5 & 7 & 9 & 10 & 1 & 9 & 12 & 5 & İ & 12 \\
\hline & 4 & 7 & İ & 9 & 7 & 5 & 7 & 10 & 7 & 3 & 9 & 3 & 1 & İ & 7 & İ & 7 & 9 & 9 & 3 & 1 & 9 & 9 & 10 & 9 & 5 & 1 & İ & 1 \\
\hline \multirow{4}{*}{1} & 1 & 1 & 1 & 1 & İ & 1 & 1 & İ & 9 & 10 & 3 & İ & 1 & 3 & 5 & 9 & 5 & 1 & İ & 9 & 1 & 1 & 5 & 7 & 3 & 3 & 5 & İ & 5 \\
\hline & 2 & 1 & 5 & 9 & İ & 1 & 1 & I & 9 & 9 & 6 & İ & 9 & 1 & 1 & 10 & 9 & 3 & İ & 10 & 1 & 5 & 5 & 9 & 6 & 7 & 3 & İ & 9 \\
\hline & 3 & 5 & 7 & 9 & İ & 3 & 1 & İ & 10 & 9 & 9 & İ & 1 & 1 & 1 & 3 & 7 & 3 & $\dot{I}$ & 9 & 5 & 1 & 1 & 7 & 9 & 7 & 3 & $\dot{I}$ & 1 \\
\hline & 4 & 5 & 7 & 10 & İ & 5 & 9 & İ & 3 & 3 & 9 & İ & 12 & 9 & 1 & 9 & 1 & 9 & İ & 1 & 1 & 1 & 3 & 9 & 9 & 1 & 5 & İ & 1 \\
\hline \multirow{4}{*}{2} & 1 & I & 11 & 11 & 11 & 11 & I & İ & 11 & 11 & 11 & İ & İ & İ & 11 & 11 & 11 & 11 & İ & 11 & İ & 11 & İ & İ & İ & 11 & İ & 11 & 11 \\
\hline & 2 & İ & 12 & 11 & 11 & 11 & İ & İ & 12 & 12 & 11 & İ & İ & İ & 12 & 12 & 12 & 11 & İ & 12 & İ & 12 & İ & $\dot{\mathrm{I}}$ & $\dot{\mathrm{I}}$ & 12 & $\dot{I}$ & 12 & 12 \\
\hline & 3 & $\dot{\mathrm{I}}$ & 12 & 12 & 12 & 12 & İ & I & 12 & 12 & 12 & $\dot{\mathrm{I}}$ & İ & İ & 12 & 12 & 12 & 12 & İ & 12 & İ & 12 & İ & İ & $\dot{I}$ & 12 & İ & 12 & 12 \\
\hline & 4 & İ & 12 & 12 & 12 & 12 & İ & İ & 11 & 12 & 12 & İ & İ & İ & 11 & 11 & 12 & 12 & $\dot{I}$ & 11 & İ & 11 & İ & $\dot{\mathrm{I}}$ & İ & 11 & İ & 11 & 11 \\
\hline
\end{tabular}




\section{EK-2 devamı}

\begin{tabular}{|c|c|c|c|c|c|c|c|c|c|c|c|c|c|c|c|c|c|c|c|c|c|c|c|c|c|c|c|c|c|}
\hline & $\mathbf{k}$ & 1 & & & & & 6 & 7 & 8 & 9 & 10 & 11 & 22 & 13 & 14 & 15 & 16 & 17 & 18 & 19 & 20 & 21 & 2 & 23 & 24 & 25 & \begin{tabular}{|l|}
26 \\
\end{tabular} & 27 & 28 \\
\hline & 1 & 1 & & 1 & & 1 & 1 & I & 5 & & & & & & 1 & 7 & 3 & 1 & & & & & & & & & & & 1 \\
\hline & 2 & 5 & i & & & 1 & & & & & & & & & & & & & & & & & & & & & & & \\
\hline & 3 & & & & & 5 & & & & & & & & $\dot{j}$ & 9 & & & ? & & & & & & & & & & & \\
\hline & 4 & 5 & & & & 7 & 7 & I & 5 & & & & 2 & $\dot{\mathrm{I}}$ & 1 & & & 5 & & & & & & & 12 & & & 1 & 1 \\
\hline & 1 & 1 & & & & & & 1 & & & & & & & & & & & & & & & & & & & & & \\
\hline & 2 & I & & & & & & & 5 & & & & & & & & & & & & & & & & & & & & \\
\hline & 3 & İ & 5 & & & & 5 & 1 & 1 & & & İ & & $\dot{I}$ & , & & & 3 & & & & $\dot{\mathrm{I}}$ & & & 3 & & 7 & 1 & I \\
\hline & 4 & i & & & & & 7 & 7 & 7 & & & & & 1 & & & & & 12 & & & & & & & & 12 & & I \\
\hline & 1 & 1 & & & & & & 1 & I & & & & & 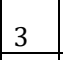 & & & & & & & & & & & & & & 3 & $f^{\prime}$ \\
\hline & 2 & 3 & 1 & 5 & & 5 & I & 7 & İ & & 5 & & & 1 & & 3 & & 3 & & & & & & İ & & & & & 7 \\
\hline & 3 & 7 & 3 & 9 & & 5 & I & 9 & İ & & 5 & & 7 & 2 & & 1 & & 5 & & & & & & İ & & & & & 7 \\
\hline & 4 & 7 & & & & 5 & \begin{tabular}{|l}
$\mathrm{I}$ \\
\end{tabular} & 12 & I & & 12 & 4 & & & & & & & & 12 & & & & & & & 12 & & 7 \\
\hline & 1 & I & & & & 3 & 3 & $\dot{I}$ & $\dot{I}$ & & & & & & - & 1 & & \pm & & & & & $\mathrm{i}$ & & & & & & I \\
\hline & 2 & İ & 1 & 2 & & 7 & 3 & I & İ & 1 & & & & & 1 & $1_{1}$ & & 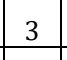 & & & & & $\dot{I}$ & & & & & 9 & $\dot{I}$ \\
\hline & 3 & I & 3 & 5 & 9 & 7 & $\underline{5}$ & I & I & $\dot{\mathrm{I}}$ & 9 & & 12 & 12 & 12 & 3 & & 9 & 3 & İ & & & i & & & 3 & & 1 & I \\
\hline & 4 & İ & 5 & & 1 & 12 & +5 & $\dot{I}$ & I & & 12 & & & & 9 & & & 12 & 3 & & & & & & & & & 5 & İ \\
\hline & 1 & 1 & & & & & 1 & 1 & 9 & & & & & & & & & & & & & & & & 12 & & & & \\
\hline & 2 & 3 & $\dot{\mathrm{I}}$ & 5 & & $\dot{\mathrm{I}}$ & 1 & 3 & 5 & 3 & 3 & $\dot{I}$ & $\dot{I}$ & 1 & 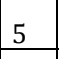 & İ & 7 & 5 & 12 & 1 & & İ & & İ & 3 & & 12 & & 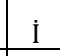 \\
\hline & 3 & 5 & I & 9 & & $\dot{\mathrm{I}}$ & 1 & 5 & $\underline{3}$ & 3 & 5 & İ & í & 5 & 5 & İ & 1 & 9 & 5 & 5 & 5 & i & 1 & $\dot{\mathrm{I}}$ & ; & 5 & 1 & 5 & I \\
\hline & 4 & 7 & & & & & & & & & & & & & & & & 12 & & & & & & & & & & & \\
\hline \multirow{4}{*}{2} & 1 & I & & & & 3 & & & İ & & & & & 5 & 7 & & & & i & & & & & & & & & 1 & 1 \\
\hline & 2 & $\dot{I}$ & $\mathrm{I}$ & 3 & 1 & 3 & 5 & 5 & I & $\dot{\mathrm{I}}$ & 5 & 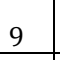 & 1 & 5 & 5 & 5 & 3 & 7 & $\dot{I}$ & 3 & I & 3 & I & 5 & 1 & İ & 3 & 5 & 5 \\
\hline & 3 & İ & 1 & & & 3 & 9 & & I & & & & & & & & & & & & & & & & & & & & \\
\hline & $T$ & & & & & 9 & & & & & & & & & & & & & & & & & & & & & & & \\
\hline & 1 & 1 & İ & & & $\dot{I}$ & 5 & 5 & İ & 5 & 1 & $\dot{I}$ & 5 & 1 & $L$ & $\mathrm{i}$ & 3 & 3 & 3 & $\dot{I}$ & 5 & & İ & $\dot{I}$ & 1 & 3 & 7 & 5 & 5 \\
\hline & 2 & 3 & İ & 3 & & İ & 5 & 5 & I & & 3 & 1 & 2 & 5 & & & & 3 & & 1 & & & 1 & 1 & & 5 & 1 & 5 & 1 \\
\hline & 3 & 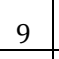 & & & & & & & & & & & & & & & & & & & & & & $\therefore$ & & & & L & 3 \\
\hline & 4 & 9 & I & & & İ & 5 & & j. & 3 & 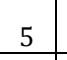 & $\dot{I}$ & & 7 & 5 & & & 12 & 5 & $\dot{I}$ & & 12 & İ & I & & 12 & & 5 & 5 \\
\hline & 1 & i & 1 & 5 & 1 & 1 & 1 & 3 & 5 & - & 3 & 9 & 3 & 1 & & & & 1 & I & & & & & & & & 7 & 5 & i \\
\hline & 2 & 1 & 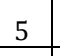 & 5 & 1 & 1 & 5 & 7 & 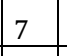 & & 3 & & 1 & 年 & & & & & 1 & & & & & & 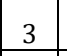 & & & & $\dot{\mathrm{I}}$ \\
\hline & 3 & 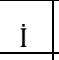 & 5 & & & 5 & 5 & 7 & 5 & & 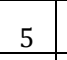 & & & 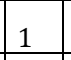 & & 12 & & & & & & & & & & & & & $\dot{I}$ \\
\hline & 4 & I & 7 & & $\mathrm{i}$ & 5 & 7 & 1 & 1 & & 7 & 3 & & 1 & & & & & If & & & & & & & I & 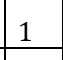 & 5 & $\dot{\mathrm{I}}$ \\
\hline & 1 & 1 & 1 & 1 & & & 11 & 1 & $\dot{I}$ & -1 & 1 & 11 & 11 & \begin{tabular}{|l|} 
\\
\end{tabular} & 1 & & & 1 & 11 & & 11 & 1 & 11 & 11 & 1 & & 11 & 1 & I \\
\hline & 2 & 1 & I & 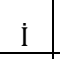 & & 1 & 1 & 1 & 1 & & $\dot{I}$ & - & 12 & 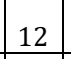 & & & & 1 & $t$ & 1 & 12 & I & \begin{tabular}{|l|}
12 \\
\end{tabular} & 12 & & 1 & 2 & I & İ \\
\hline & 3 & 1 & I & $\dot{I}$ & $\mathrm{i}$ & & & & $\dot{\mathrm{I}}$ & İ & İ & & & & & & & İ & & & & & 12 & & & I & 2 & İ & \\
\hline & 4 & 1 & I & 1 & 1 & 1 & 1 & 1 & I & _ & İ & 11 & 11 & 11 & 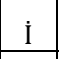 & & 1 & İ & 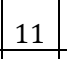 & $\mathrm{i}$ & 1 & İ & 11 & 12 & 12 & İ & 11 & I & $\dot{\mathrm{I}}$ \\
\hline & 1 & 1 & $\pi$ & 1 & 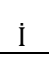 & 1 & 5 & 5 & 1 & 1 & 1 & -1 & 1 & 5 & 5 & 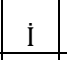 & 11 & I & 1 & İ & 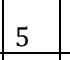 & 3 & 1 & $\dot{I}$ & 1 & 1 & $\dot{I}$ & 5 & 5 \\
\hline & 2 & I & $\dot{I}$ & $\dot{\mathrm{I}}$ & 1 & 1 & 5 & 5 & i & 1 & 1 & : & & 5 & 5 & & 1 & 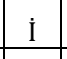 & 1 & I & & & İ & 1 & 1 & 1 & $\dot{I}$ & 5 & \\
\hline & 3 & $\mathrm{I}$ & İ & $\mathrm{I}$ & İ & 1 & 5 & 5 & İ & 1 & I & - & & 5 & 5 & & 1 & i & İ & 1 & & & $\mathrm{I}$ & I & 1 & İ & İ & 3 & 3 \\
\hline & 4 & & & & & & & & & & & & & & & & & & & & & & & & & & & & \\
\hline
\end{tabular}




\section{EK-2 devamı}

\begin{tabular}{|c|c|c|c|c|c|c|c|c|c|c|c|c|c|c|c|c|c|c|c|c|c|c|c|c|c|c|c|c|c|}
\hline i & $\mathbf{k}$ & 1 & & & 4 & 5 & 6 & 7 & 8 & 9 & 10 & 11 & 12 & 13 & 14 & 15 & 16 & 17 & 18 & 19 & 20 & 21 & 22 & 23 & 24 & 25 & 26 & 27 & 28 \\
\hline \multirow{4}{*}{3} & 1 & I & & & & & 5 & 3 & I & & & & & 5 & 5 & & & & & & & & & & i & & j̇ & 5 & 5 \\
\hline & 2 & I & & & & & & & 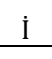 & & & & & 5 & & & & & & & & & & & & & & & \\
\hline & 3 & İ & & & & & & & I & & I & & 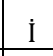 & 5 & 5 & & & i & $\dot{I}$ & $i$ & & & $\dot{x}$ & & & & j & 3 & 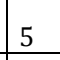 \\
\hline & 4 & İ & & & & & 12 & 5 & $\dot{\mathrm{I}}$ & 1 & İ & & $\dot{I}$ & 5 & 5 & & & İ & & İ & & & & $\dot{I}$ & & $i$ & I & 5 & 5 \\
\hline & 1 & İ & & & & & 5 & 5 & İ & & İ & & & 5 & 5 & & & & & & & & & & $\dot{t}$ & & $\mathrm{i}$ & 3 & 5 \\
\hline & 2 & I & & & & & 5 & 5 & I & & & & & 5 & 12 & & & & & & & & & & & & 1 & & \\
\hline & 3 & $\dot{\mathrm{I}}$ & $\dot{\mathrm{I}}$ & $\dot{\mathrm{I}}$ & & & 5 & 5 & $\dot{\mathrm{I}}$ & $\mathrm{I}$ & $\dot{\mathrm{I}}$ & $\dot{\mathrm{I}}$ & $\dot{I}$ & 3 & 5 & $\dot{i}$ & $\dot{j}$ & $\dot{I}$ & $j$ & I & 5 & 5 & İ & $\dot{\mathrm{I}}$ & I & $\dot{I}$ & $\dot{\mathrm{I}}$ & 5 & 5 \\
\hline & 4 & İ & $\dot{\mathrm{I}}$ & & $\mathrm{j}$ & & 5 & 5 & İ & $\mathrm{i}$ & ì & & $\dot{\jmath}$ & 5 & 5 & & & & & İ & & & $\dot{\mathbf{I}}$ & & & & İ & 5 & 5 \\
\hline \multirow{4}{*}{3} & 1 & I & & & & & 3 & 3 & I & & 1 & & 1 & 5 & 9 & & & & & 1 & & & & & & & I & & 3 \\
\hline & 2 & I & $\dot{\mathrm{I}}$ & $\dot{\mathrm{I}}$ & i & & 5 & 5 & $\dot{\mathrm{I}}$ & 1 & I & & I & 3 & 12 & & & $\dot{I}$ & 1 & İ & & 12 & 1 & $\dot{\mathrm{I}}$ & $\dot{I}$ & $\dot{I}$ & $\dot{\mathrm{I}}$ & 12 & 12 \\
\hline & 3 & I & İ & & $\dot{\mathrm{I}}$ & & 9 & 5 & $\dot{I}$ & İ & $\dot{I}$ & $\dot{\mathrm{j}}$ & $\dot{\jmath}$ & 9 & 3 & & & $\dot{\mathrm{d}}$ & $\dot{I}$ & İ & & & $\mathrm{I}$ & $\dot{\mathrm{d}}$ & $\dot{j}$ & $\dot{I}$ & İ & 9 & 5 \\
\hline & 4 & I & 1 & & & & 12 & 5 & I & 1 & I & & I & 12 & 5 & & & 1 & & İ & 12 & & I & $\mathrm{i}$ & 1 & 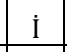 & İ & 12 & 5 \\
\hline & 1 & 1 & $\underline{1}$ & & & & 3 & 5 & $\dot{\mathrm{I}}$ & İ & I & & İ & 5 & 5 & 1 & & 1 & 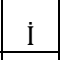 & I & 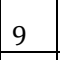 & & İ & $\dot{I}$ & $\dot{\mathrm{I}}$ & $\dot{I}$ & $\dot{I}$ & 5 & 3 \\
\hline & 2 & İ & $\mathrm{I}$ & 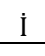 & $\dot{I}$ & & 5 & 5 & I & I & $\dot{j}$ & $i$ & I & 5 & 3 & & & $\mathrm{i}$ & $\dot{I}$ & I & 12 & & 1 & 1 & & & i & 3 & 2 \\
\hline & 3 & İ & $\dot{\mathrm{I}}$ & $\dot{\mathrm{I}}$ & $\dot{\mathrm{I}}$ & $\dot{\mathrm{I}}$ & 9 & 5 & $\dot{\mathrm{I}}$ & I & $\mathrm{I}$ & İ & $\dot{\mathrm{I}}$ & 3 & 5 & 1 & $\dot{\mathrm{I}}$ & $\dot{\mathrm{I}}$ & İ & I & 12 & 5 & $\mathrm{I}$ & İ & İ & İ & $\dot{I}$ & 12 & 5 \\
\hline & 4 & $\dot{\mathrm{I}}$ & í & I & $\dot{\mathrm{I}}$ & & 12 & 5 & $\dot{\mathrm{I}}$ & İ & $\dot{\mathrm{I}}$ & 1 & $\dot{I}$ & 5 & 3 & 1 & 1 & $\dot{I}$ & I & I & 9 & 5 & İ & $\dot{I}$ & İ & I & I & 9 & 3 \\
\hline & 1 & İ & $\dot{\mathrm{I}}$ & & & & 5 & 3 & İ & _ & İ & & & 9 & & & & & & & & & & & & & & & \\
\hline & 2 & İ & $\dot{\mathbf{I}}$ & $\dot{\mathrm{d}}$ & $\dot{i}$ & $\dot{\mathrm{I}}$ & 9 & 3 & I & İ & İ & $i$ & $\dot{\mathrm{I}}$ & 5 & 5 & & & $\dot{i}$ & $\dot{\mathbf{I}}$ & İ & & 12 & $i$ & $\dot{\mathrm{I}}$ & $\dot{\mathrm{I}}$ & $\dot{\mathbf{I}}$ & İ & 5 & 5 \\
\hline & 3 & $\mathrm{I}$ & İ & I & İ & I & 9 & 5 & $\dot{\mathrm{I}}$ & $\dot{\mathrm{I}}$ & $\dot{\mathrm{I}}$ & I & $\dot{I}$ & 12 & 9 & İ & İ & $\dot{\mathrm{I}}$ & $\dot{\mathrm{I}}$ & $\mathrm{I}$ & 5 & 9 & $\dot{\mathrm{I}}$ & $\dot{\mathrm{I}}$ & I & İ & $\dot{\mathrm{I}}$ & 5 & 5 \\
\hline & 4 & I & 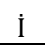 & & & & 1 & 5 & İ & 1 & İ & & 1 & 5 & 12 & & & & & 1 & & & & & & & & 12 & 5 \\
\hline & 1 & I & & & & & 3 & 9 & I & $\dot{\mathrm{I}}$ & İ & & $\therefore$ & 5 & 9 & & & & & j & & & $\dot{I}$ & & & & $\dot{I}$ & 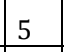 & J \\
\hline & 2 & I & İ & $\dot{\mathrm{I}}$ & I & $\dot{\mathrm{I}}$ & 5 & 9 & İ & $\dot{\mathrm{I}}$ & İ & I & İ & 9 & 3 & İ & İ & I & İ & İ & 5 & 5 & I & İ & I & İ & İ & 3 & 5 \\
\hline & 3 & $\mathrm{I}$ & $\dot{\mathrm{I}}$ & $\dot{\mathrm{I}}$ & $\dot{\mathrm{I}}$ & $\dot{I}$ & 9 & 12 & $\dot{\mathrm{I}}$ & I & I & $\dot{\mathrm{I}}$ & I & 5 & 12 & $\dot{I}$ & $\dot{I}$ & İ & İ & I & 3 & 5 & İ & i & I & I & İ & 12 & 3 \\
\hline & 4 & İ & 1 & & & & & & 1 & & 1 & & & $?$ & 3 & & & & & & & & & & & & & 9 & \\
\hline \multirow{4}{*}{3} & 1 & $\dot{I}$ & $\dot{\mathrm{I}}$ & & İ & & 3 & 3 & $\dot{\mathrm{I}}$ & İ & $\dot{\mathrm{I}}$ & I & İ & 9 & 3 & $\dot{\mathrm{I}}$ & İ & $j$ & İ & İ & 5 & 5 & I & $\dot{I}$ & I & İ & $\dot{I}$ & 5 & 9 \\
\hline & 2 & İ & İ & $\dot{\mathrm{I}}$ & $\dot{\mathrm{I}}$ & $\dot{I}$ & 3 & 3 & $\dot{\mathrm{I}}$ & $\dot{\mathrm{I}}$ & I & $\dot{\mathrm{I}}$ & I & 3 & 5 & İ & İ & i & $\dot{I}$ & I & 5 & 5 & $\dot{\mathrm{I}}$ & $\mathrm{I}$ & I & İ & İ & 9 & 12 \\
\hline & 3 & İ & I & 1 & I & $\dot{\mathrm{I}}$ & 5 & 5 & I & $\dot{\mathrm{I}}$ & İ & 1 & İ & 5 & 5 & & 1 & $\dot{I}$ & 1 & I & 12 & & $\dot{\mathrm{I}}$ & $\dot{I}$ & İ & 1 & $\dot{I}$ & 3 & 12 \\
\hline & 4 & 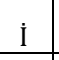 & 1 & & & & 5 & 9 & İ & & $\dot{I}$ & & $j$ & 12 & 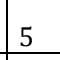 & & & $\dot{I}$ & 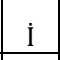 & İ & & & $\dot{I}$ & $\dot{I}$ & $\dot{\mathrm{I}}$ & 1 & I & 5 & 9 \\
\hline & 1 & İ & İ & $\dot{\mathrm{I}}$ & I & I & 5 & 3 & I & $\dot{j}$ & İ & $\dot{I}$ & İ & 3 & 9 & $\dot{I}$ & İ & İ & İ & İ & 9 & 5 & $\dot{\mathrm{I}}$ & I & İ & $\dot{I}$ & İ & 9 & 5 \\
\hline & 2 & $\dot{\mathrm{I}}$ & İ & i & $\dot{\mathrm{I}}$ & $\dot{I}$ & 5 & 5 & İ & $\dot{\mathrm{i}}$ & İ & $\dot{\mathrm{I}}$ & İ & 3 & 3 & i & 1 & İ & I & İ & 12 & 5 & I & $\mathrm{I}$ & 1 & İ & İ & 12 & 5 \\
\hline & 3 & $\mathrm{i}$ & 1 & 1 & I & $\mathrm{I}$ & 9 & 9 & 1 & $\mathrm{I}$ & İ & 1 & I & 5 & 3 & 1 & 1 & $\dot{\mathrm{I}}$ & İ & İ & c & 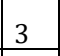 & İ & $\dot{\mathrm{I}}$ & I & 1 & \begin{tabular}{|l|} 
\\
\end{tabular} & 5 & 5 \\
\hline & 4 & 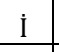 & $\dot{I}$ & 1 & I & & 1 & 1 & $\dot{\mathrm{I}}$ & I & I & $\dot{I}$ & I & 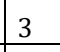 & 12 & I & I & 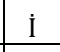 & I & 2 & & ᄃ & $\dot{\mathrm{I}}$ & $\dot{\mathrm{I}}$ & İ & I & İ & 9 & 12 \\
\hline & 1 & $\dot{\mathrm{I}}$ & $\mathrm{I}$ & I & $\dot{I}$ & $\dot{\mathrm{I}}$ & 3 & 3 & $\dot{\mathrm{I}}$ & I & $\dot{\mathrm{I}}$ & $\dot{\mathrm{I}}$ & $\dot{I}$ & 9 & 3 & $\dot{\mathrm{I}}$ & $\dot{I}$ & I & I & $\dot{I}$ & 3 & 5 & $\dot{\mathrm{I}}$ & $\mathrm{I}$ & İ & İ & I & 3 & 3 \\
\hline & 2 & 1 & 1 & 1 & 1 & İ & 3 & 3 & I & İ & I & 1 & İ & 3 & 5 & 1 & 1 & $\mathrm{i}$ & \begin{tabular}{|l|}
$\mathrm{I}$ \\
\end{tabular} & I & 3 & 9 & İ & I & \begin{tabular}{|l|}
$\mathrm{I}$ \\
\end{tabular} & $\mathrm{I}$ & \begin{tabular}{|l|l} 
\\
\end{tabular} & 5 & 3 \\
\hline & 3 & $\dot{\mathrm{I}}$ & İ & 1 & $\dot{I}$ & 1 & 3 & 5 & I & $\dot{\mathrm{I}}$ & I & 1 & $\dot{\mathrm{I}}$ & 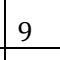 & . & 1 & 1 & $\therefore$ & : & i & 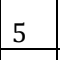 & 12 & İ & 1 & I & 1 & 1 & 5 & 9 \\
\hline & 4 & İ & & & $\dot{I}$ & $\dot{x}$ & 5 & 5 & $\dot{I}$ & $\dot{\mathrm{I}}$ & $\dot{I}$ & & & 12 & & & & $\dot{\mathrm{I}}$ & $\dot{\mathrm{j}}$ & $\dot{I}$ & & & İ & 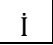 & $\dot{I}$ & İ & & 3 & \\
\hline
\end{tabular}

